\title{
NILAI-NILAI PLURALISME DALAM TAFSIR NUSANTARA
}

\author{
Munzir Hitami \\ Guru Besar UIN Suska Riau \\ e-mail: mzr.hitami@gmail.com
}

Abstrak:

Artikel ini merupakan hasil penelitian literature dengan fokus pada ayat al-Qur'an yang berkenaan dengan nilai-nilai pluralisme agama. Sedangkan tafsir yang digunakan adalah tafsir yang di tulis ole beberapa ulama dan intelektual muslim Nusantara. Penelitian ini, menjadi penting ketika kesadaran akan pluralisme agama di Indonesia semakin tergerus oleh perkembangan politik, budaya, dan lainnya. Maka mengkaji para ulama tafsir Indonesia menjadi sangat penting untuk dilakuakan. Meskipun terjadi perbedaan penafsiran karena terjadi perbedaan ruang dan waktu, namun demikian terdapat beberapa nilai yang memberikan kesimpulan yang sama, yaitu Pertama, Mengakui eksistensi agama lain; Kedua, memberinya bak untuk bidup berdampingan saling menghormati pemeluk agama lain tanpa ada unsur kecurigaan. Ketiga, Larangan adanya unsur paksaan dalam beragama. Keempat, kesatuan ajaran dan Kelima, pengakuan keselamatan pada masing-masing agama.

Kata Kunci: pluralism, tafsir, ulama nusantara

Abstract:

This article is the result of literature research with a focus on verses of the Qur'an relating to the values of religious pluralism. While the interpretation used is the interpretation written by several Muslim scholars and intellectuals of the archipelago. This research becomes important when awareness of religious pluralism in Indonesia is increasingly eroded by political, cultural, and other developments. So it is very important to study the scholars of Indonesian interpretation. Although there are differences in interpretation due to differences in space and time, however, there are several values that give the same conclusion, namely First, to acknowledge the existence of other religions; Second, it gives him the right to live side by side with mutual respect for followers of other religions without any element of suspicion. Third, the probibition of the element of coercion in religion. Fourth, the unity of the teachings and Fifth, the recognition of salvation in each religion.

Keywords: pluralism, interpretation, Indonesian scholar's

\section{PENDAHULUAN}

Diantara diskursus yang masih menuai kontraversi hingga saat ini adalah persoalan pluralitas agama. Lebih-lebih pada tanggal 29 Juli 2005 Majelis Ulama Indonesia (MUI) Pusat menerbitkan keputusan fatwa (No.
7/MUNAS VII/MUI/II/2005) berkenaan dengan keharaman paham pluralisme, liberalisme dan sekularisme. ${ }^{1}$ Protes keras
1 Tulisan yang cukup menarik dalam merekam kontraversi fatwa tersebut adalah buku Budhy MunawarRachman, Reorientasi Pembaruan Islam: Sekularisme, Liberalisme dan Pluralisme, Paradigma Baru Islam Indonesia (Jakarta: Lembaga Studi Agama dan Filsafat (LSAF) dan Paramadina, 2010), 554- 567 


\section{NUSANTARA; Journal for Southeast Asian Islamic Studies}

Vol. 17, No. 1, Juni 2021

pun bermunculan, ${ }^{2}$ meskipun tidak sedikit yang setuju dengan fatwa tersebut. ${ }^{3}$

Nusantara merupakan negeri yang memiliki jumlah penduduk lebih dari 200 juta jiwa, dengan 17.800 pulau kecil dan besar. Menurut data Badan Pusat Statistik (BPS) Republik Indonesia pada tahun 2000, menyebutkan bahwa jumlah suku di Indonesia, yang berhasil terdata sebanyak 1.128 suku bangsa, dengan komposisi 1.072 etnik dan sub-etnik di Indonesia. Sementara Wakil Menteri Pendidikan dan Kebudayaan Windu Nuryanti (2012), mengatakan bahwa menurut hasil penelitian Indonesia memiliki sekitar 743 bahasa. $^{4}$ Dari jumlah itu, 442 bahasa sudah dipetakan oleh Badan Pengembangan dan Pembinaan Bahasa, sebanyak 26 bahasa diantaranya ada di Sumatera, 10 bahasa di Jawa dan Bali, 55 bahasa di Kalimantan, 58 bahasa di Sulawesi, 11 bahasa di Nusa Tenggara Barat, 49 bahasa di Nusa Tenggara Timur, 51 bahasa di Maluku, serta 207 bahasa di Papua. Kondisi ini, Indonesia sungguh menjadi salah satu negara dengan tingkat keaneragaman budaya atau tingkat heterogenitas yang sangat tinggi. Tidak saja keanekaragaman budaya kelompok suku bangsa namun juga keanekaragaman budaya dalam konteks peradaban, tradisional hingga ke modern, dan kewilayahan.

Sehingga Hefner pernah menyampaikan bahwa: Pluralisme kultural di Asia Tenggara, khususnya Indonesia, Malaysia, dan Singapura sangatlah mencolok,

2 Diantara tokoh yang menolak pandangan MUI tersebut adalah Faisal Ismail (Guru Besar UIN Sunan Kalijaga Yogyakarta). Beliau menulis di Koran Sindo, edisi Jum'at 7 Februari 2014, "apa yang salah dengan pluralisme agama?”. Dalam tulisan ini, Faisal Ismail menegaskan "tidak ada agama yang mengandung ajaran yang mutlak. Dan beranggapan babwa tidak ada yang salah dengan pluralisme agama. Yang terlihat salah, menurut pendapat saya, adalab sinkretisme agama. Salah seorang pimpinan MUI di sebuah televisi menjelaskan, yang diharamkan MUI adalah pluralisme agama yang ditarik ke sinkretisme agama.". Zuhairi Misrawi dalam bukunya $A l$ Qur'an Kitab Toleransi: Inklusivisme, Pluralisme, dan Multikulturalisme (Jakarta: Fitrah, 2007) hlm. 207, juga menjelaskan secara detail beberapa kekeliruan dalam Fatwa MUI tersebut.

${ }^{3}$ Kelompok yang menerima diantaranya adalah yaitu Hamid Fahmy Zarkasyi yang merupakan Pimpinan Ponpes Modern Gontor Ponorogo dan direktur INSISTS (Institute for the Study of Islamic Thought and Civilization), Adian Husaini alumnis ISTAC Malaysia, Adnin Armas merupakan Ketua Yayasan Keadilan untuk Semua (YKUS), dari kalangan muda yaitu Akmal Sjafril, adapun basisnya berasal dari Program terdapat hanya beberapa wilayah lain di dunia yang memiliki pluralisme kultural seperti itu. ${ }^{5}$ Karena itulah dalam teori politik Barat di tahun 1930-an dan 1940-an, wilayah ini, khususnya Indonesia dipandang sebagai "lokus klasik" bagi konsep masyarakat majemuk/plural (plural society) yang diperkenalkan ke dunia Barat oleh JS Furnivall. Pandangan Hefner ini, bagi konsep masyarakat majemuk bukan sesuatu yang berlebihan. Hal ini terlihat dari keberagaman yang dimiliki Indonesia sebagai bangsa yang unik dimana hanya beberapa wilayah saja di dunia yang dianugrahi keistimewaan ini.

Secara sosiologis, adanya pluralisme tersebut menjadi modal sosial untuk mengarahkan konsep pluralisme tidak hanya pada tataran teologis an sich. ${ }^{6}$ Melainkan meletakkannya kepada wilayah ideologis dengan mengejawantah pada etika sosial dalam kehidupan yang heterogen. Sehingga, pluralisme ditegakkan sebagai cara pandang dalam melihat orang lain sebagai bagian dari sistem sosial yang harus dihargai. ${ }^{7}$ Dan pluralisme digunakan sebagai dasar pemahaman yang inklusif dalam menentukan pandangan kita terhadap agamaagama lain. Dengan demikian, akan bisa arif melihat setiap perbedaan yang ada di dalam kemajemukan, dan bisa jadi akan memotivasi antara satu dengan yang berbeda untuk saling berlomba menuju kebaikan. ${ }^{8}$

Namun demikian, tidak jarang prluralisme agama di negeri ini juga menjadi bencana. Berbagai

Pascasarjana Pendidikan dan Pemikiran Islam Universitas Ibn Khaldun Bogor, serta mereka yang tergabung di dalam Majelis Intelektual dan Ulama Muda Indonesia (MIUMI). Lihat Subkhi Ridho, "Kelas Menengah Muslim Baru dan Kontestasi Wacana Pluralisme di Media Sosial" dalam Jurnal Pemikiran Sosiologi Volume 4 No. 2 , Agustus 2017, 96.

${ }^{4}$ http://www.menkokesra.go.id

5 Choirul Mahfud, Pendidikan Multikultural. (Yogyakarta: Pustaka Pelajar, 2009), 83

${ }^{6}$ Patut disadari, bila pluralism diletakkan pada wilayah teologis, maka akan melahirkan kelompok puritan teologis yang akan selalu mengakui bahwa agamanya adalah yang paling benar dan memahami ajarannya secara literlek yang kemungkinan besarnya akan turut mengkafirkan ummat lain yang berbeda agama. Lebih jelas baca, Abdullah Saeed, Pemikiran Islam: Sebuah Pengantar, terj (Yogyakarta: Kaukaba, 2014), 264-266

7 Heru Nugroho, Menumbubkan Ide-ide Kritis (Yogyakarta: Pustaka pelajar, 2001), 174

8 Budhy Munawar Rahman, Islam Pluralis: Wacana Kesetaraan Kaum Beriman (Jakarta: Paramadina, 2001), 46-48 
konflik atas nama agama, tidak jarang bermunculan. Dalam catatan Gavin W. Jones, konflik dan ketegangan antar penganut agama di Indonesia diantaranya: konflik Kristen-Islam tahun 1950-an di Aceh dan di desa-desa Kristen di wilayah Toraja Sulawesi Selatan, dan keteganganketegangan pada akhir tahun 1960-an yang bersumber pada reaksi umat Islam terhadap peningkatan besar-besaran jumlah jama'ah gereja seperti Jawa Timur, Jawa Tengah serta Batak Karo di Sumatera Utara. ${ }^{9}$ Menurut keterangan Alwi Shihab, pada tahun 1931 jumlah umat Krinten di Indonesia 2,8 \% dari jumlah penduduk. Pada tahun 1971 menjadi 7,4\% dan pada tahun 1990 meningkat menjadi 9,6\%. ${ }^{10}$ Pada tahun 90 -an ketegangan antar umat beragama juga terjadi, bahkan menjadi peristiwa yang diwarnai dengan kekerasan. Hal ini terjadi di berbagai tempat seperti di Timor-Timur, Surabaya, Situbondo, Kalimantan Barat, Tasikmalaya, Jakarta Ambon dan sebagainya.

Al-Qur'an sebagai wahyu dan firman Allah, menempati posisi sentral dalam Islam. Sehingga pemahaman atas ayat-ayat yang ada didalamnya, akan mempengaruhi sikap dan perilaku penganutnya. Sebagai wahyu, maka al-Qur'an merupakan sebuah pencerahan, sebuah bukti atas realitas dan sebuah penegasan kebenaran. Ia adalah sebuah tanda yang jelas, sebuah bukti atau indikasi, makna atau signifkansi, bagi seorang pemerhati, yang harus diamati, direnungkan dan dipahami. Dari wahyu akan memunculkan gagasan, saran, pemikiran, penemuan ilmiah, tatanan sosial yang egaliter, dan ditemukannya kebenaran ilahi,

${ }^{9}$ Gavin W. Jones, "Agama-Agama di Indonesia: Sejarah dan Perkembangannya", dalam Agama dan Tantangan Zaman, Pilihan Artikel Prisma 1975-1984 (Jakarta: LP3ES, 1985), 116.

10 Alwi Shihab, "Pertemuan Islam-Kristen di Indonesia, Sebuah Timjauan Historis", dalam bukunya Islam Inklusif, Menuju Sikap Terbuka dalam Beragama, ed Nurul A Rustamdji, (Bandung: Mizan, 1997), 20.

11 Ziaul Haque, Wabyu dan Revolusi, terj. E. Setiyawati Al Khatab (Yogyakarta: LKiS, 2000), 9.

12 Secara etimologis kata al-Ma'tsur merupakan isim maf'ul dari kata Atsara yang berarti sesuatu yang dinukilkan. Sedangkan terminologi kata al-Ma'tsur dalam istilah ilmu tafsir berarti sesuatu yang diberitakan baik itu berasal dari ayat-ayat Al-Qur'an, hadis Rasuluallah, pendapat para sahabat, dan para tabi'in guna menjelaskan maksud alQur'an. Dengan demikian tafsir bi al-Ma'tsur adalah usaha memahami ayat-ayat Al-Qur'an dengan mencari keterangan- memperkaya pengetahuan, petunjuk dan kesejahteraan manusia serta membebaskan pikiran-pikiran, moral, dan emosi-emosi yang terbelenggu dan meninggikan harkat dan martabat manusia yang tertindas oleh kekuatan-kekuatan kezaliman, tirani dan tabayyul. ${ }^{11}$

Namun demikian, tidak jarang kerangka epistemologis tafsir al -Qur`an, hanya berhenti pada metode bi al-ma'tsür, ${ }^{12}$ sehingga gerak tafsir alQuran terkesan sangat teologis, pembenar dari yang maha benar (al-haq), kepastian dari yang maha absolute. Akibatnya, otoritas dan potensi kreatif manusia sebagai penafsir, menjadi terkubur. Fenomena ini oleh Khaled Abou El Fadl disebut sebagai despotisme intelektual (al-Istibdād bi alra yr), yaitu pemaksaan pendapat tanpa otoritas yang semestinya. ${ }^{13}$ Despotisme intelektual dalam penafsiran terhadap al-Qur`an ini, akan berimbas kepada cara berpikir dan bertindak umat Islam. Kelompok masyarakat yang mengikuti pandangan tersebut, akan bertindak secara otoriter karena mereka beranggapan bahwa pendapat mereka adalah kebenaran dari Tuhan yang wajib ditegakkan. ${ }^{14}$

Bagaimanapun sebuah tafsir merupakan entitas yang berbeda dengan al-Quran. Jika alQuran merupakan kebenaran yang bersifat mutlak, maka tafsir memiliki kebenaran yang bersifat relatif. Proses penafsiran tidak akan pernah mencapai batas akhir (on going prosess), ia akan terus bermunculan seiring dengan banyaknya hasil interpretasi seseorang atas al-Quran, yang mana penafsiran tersebut tidak bisa dilepaskan dari konteks di mana tafsir itu diproduksi. ${ }^{15}$

keterangan dan perincian-perinciannya dari ayat-ayat alQur'an sendiri, sunnah Rasuluallah, pendapat para sahabat, dan penjelasan para tabi'in. M. Hasbi Ash-Shiddieqy, Sejarah dan Pengantar ilmu al-Qur'an, (Jakarta: Bulan Bintang, 1990), 213; lihat juga Mahmud Basuni Faudah, al-Tafsir wa alManhajatubu, terj. Mukhtar Zein, (Bandung: Pustaka, 1987), 24

13 Khaled Abou El Fadl, Atas Nama Tuhan (Jakarta: Serambi, 2004), 142-143

14 Menurut Schward, bahwa dampak dari model pendekatan yang mereka terapkan terhadap teks al-Qur'an, membuat mereka memiliki pemahaman yang kaku terhadap hukum Islam, anti barat, dan non-muslim yang menguasai ekonomi mayoritas umat Islam, seperti China. Lihat Adam Schward, A Nation in Waiting: Indonesia Search for Stability (Washing \& Unwin, 1999), 330

15 Oleh karena itu, tafsir sangat terbuka untuk dikaji dan dikritisi. Dan tidak mustahil jika kita mempersilakan 


\section{NUSANTARA; Journal for Southeast Asian Islamic Studies}

Vol. 17, No. 1, Juni 2021

Sebagaimana yang disebut oleh Abdul Mustaqim bahwa epistemologi tafsir sangat dipengaruhi oleh latar belakang keilmuan, pandangan hidup mufasir, dan tujuan penafsiran itu sendiri. ${ }^{16}$ Meminjam analogi Abdullah Darras, dia menggambarkan bahwa ayat-ayat al-Quran bagaikan intan. Setiap sudutnya memancarkan cahaya yang berbeda dengan apa yang terpancar dari sudut lainnya. ${ }^{17}$

Misalnya pertumbuhan tafsir di Timur Tengah, tempat dimana tafsir al-Qur'an semula tumbuh dan berkembang, sebagaimana telah disurvei secara ekstentif oleh Muhammad Husayn al-Dzahabî dalam disertasinya yang kemudian diterbitkan dengan judul al-Tafsîr wa al-Mufassirûn (Tafsir dan Para Penafsir), tafsir al-Qur an sejak periode klasik hingga periode modern telah berkembang dengan berbagai corak aliran, baik Ahl al-Sunnah maupun Syîah, dan latar belakang spesialisasi keilmuan penafsir, baik kalangan teolog, fuqahâ', sufi, maupun ilmuwan. ${ }^{18}$ Demikian dinamisnya sebuah tafsir.

Tidak hanya di Timur Tengah, perkembangan pemikiran tentang tafsir al-Qur`an juga telah merambah ke berbagai belahan dunia dengan berbagai corak dan metodologinya. Di anak benua India, misalnya, juga muncul para pencetus tafsir al-Qur’an, seperti Farâhî, Ishlâhî yang terkenal dengan analisis struktur kalimat $(n a \not h m),{ }^{19}$ dan Fazlur Rahman dengan gerakan ganda (double movement) dalam teori hermeneutikanya. ${ }^{20} \mathrm{Di}$

orang lain memandangnya dari sudut lainnya, dia akan melihat lebih banyak dari apa yang kita lihat. Demikian halnya dengan sahabat Ali bin Abi Thalib yang melarang Ibnu Abbas menggunakan Al-Quran dalam mendebat orang lain, karena Al-Quran mengandung banyak wajah.Ali menyatakan bahwa Al-Quran dalam artian mushaf tidaklah sanggup berbicara, kecuali manusialah yang membuatnya berbicara.Manusia yang bertugas mengungkap pesan yang terkandung dalam Al-Quran agar dapat berfungsi memberi petunjuk. H.U Syafrudin, Paradigma Tekstual dan Kontekstual (Cet. I; Yogyakarta: Pustaka Pelajar, 2009), hlm. 2-3.

${ }^{16}$ Abdul Mustaqim, Epistemologi Tafsir Kontemporer (Cet. II; Yogyakarta: LKis, 2012), hlm. 9.

${ }^{18}$ Lihat lebih lanjut Muhammad Husayn al-Dzahabî, al-Tafsîr wa al-Mufassirun: Babts Tafshilli 'an Nays'at al-Tafsîr wa Tathawwurih wa Alwânih wa Madzâbibih ma'a 'Ardh Syâmil li Asyhar al-Mufassirin wa Tablì Kâmil li Ahamm Kutub al-Tafsì min 'Ashr al-Nabî Shallâ Allâh 'alayh wa Sallam ilâ 'Ashrinâ alHâdhir (Cairo: Dâr al-Hadits, 2005), 3 volume

${ }_{19}$ Mustansir Mir, Coberence in the Qur'an: A Study of Islâbi's Concept of Nazm in Tadabbur-i Qur'ân (Washington: American Trust Publications, 1986)
Syria, Muhammad Syahrûr, mencetuskan hermeneutika dalam memahami ayat-ayat hukum, khususnya melalui teori batas (nazhariyyat al-hadd). ${ }^{21}$ Di Afrika Selatan, beranjak dari kritik terhadap apartheid, Farid Esack melontarkan metodologi penafsiran ayat-ayat al-Qur`an dalam konteks pembebasan dari segala penindasan melalui hermenetika resepsinya (reception hermeneutics). ${ }^{22} \mathrm{Di}$ Maroko, Muhammad 'Âbid al-Jâbirî, seorang yang selama ini dikenal sebagai guru besar filsafat Islam, juga tidak hanya menulis tafsir dalam karyanya, Fabm al-Qur ân, ${ }^{23}$ melainkan juga menulis tentang metodologi tafsir dalam karyanya, Madkhal ilâ alQur ân al-Karim. ${ }^{24}$

Sebagai salah satu negara dengan penduduk mayoritas beragama Islam, Indonesia juga memiliki khazanah tafsir yang tidak kurang dari negara-negara muslim lainnya. Meskipun, menurut Nashruddin Baidan, perkembangan tafsir di Indonesia baru dimulai pada abad ke-20, namun pada hari ini, perkembangan tafsir di Indonesia tidak kalah dibandingkan dengan perkembangan di negara-negara lain, baik di Timur Tengah maupun Asia Tenggara. ${ }^{25}$ Dari segi produk penafsiran (karya-karya tafsir), sebagaimana disurvei oleh beberapa pengkaji, seperti Nashruddin Baidan, ${ }^{26}$

20 Fazlur Rahman, Islam and Modernity, terj. Ahsin Mohammad dengan judul Islam dan Modernitas, terj. (Bandung: Pustaka, 1995), h. 7-8.

${ }^{21}$ Andreas Christmann, "The Form is Permanent, But the Content Moves: the Quranic Text and Its Interpretation(s) in Mohamad Shahrour`s al-Kitâb wa alQur'ân," dalam Suha Taji-Farouki (ed), Modern Muslim Intellectual and the Qur an, (London: The Institute of Ismaili Studies, 2004).

${ }^{22}$ Farid Esack, Qur'an, Liberation, and Pluralism: an Islamic Perspective of Interreligious Solidarity Against Oppressin (Oxford: Oneworld Publications, 1997), h. 51-52

23 Muhammad 'Âbid al-Jâbirî, Fabm al-Qur'ân alHakîm: al-Tafsîr al-WâdhibHasab Tartîb al-Nuzûul (Beirut: Markaz Dirâsât al-Wahdah al-'Arabiyyah, 2008).

${ }^{24}$ Muhammad 'Âbid al-Jâbirî, Madkhal ilâ al-Qur'ân alKarîm, (Beirut: Markaz Dirâsât al-Wahdah al-'Arabiyyah, 2006)

25 Wardani, Trend Perkembangan Pemikiran Kontemporer; Metodologi Tafsiral-Qur'an di Indonesia, 6 - 7.

${ }^{26}$ Nashruddin Baidan, Perkembangan Tafsir al-Qur'an di Indonesia (Solo: Tiga Serangkai Pustaka Mandiri, 2003). 
Howard M. Federspiel, ${ }^{27}$ Islah Gusmian, ${ }^{28}$ dan M. Nurdin Zuhdi, ${ }^{29}$ tafsir Indonesia mengalami perkembangan yang pesat pada periode modern dan kontemporer.

Selain itu, beberapa riset menunjukkan bahwa yang meneliti tentang al-Qur'an di Nusantara, ${ }^{30}$ diantaranya adalah penelitian yang dilakukan oleh Izza Rohman Nahrowi dengan judul Karakteristik Kajian al-Quran di Indonesia. Namun demikian, penelitiannya hanya berkisar pada pemaparan karakter kajian alQur'an (baik itu tafsir ataupun karya-karya ulum al-Qur'an yang beredar di Indonesia pada tahun 1998-2002. ${ }^{31}$

Sedangkan penelitian yang berkaitan dengan topik pluralisme agama dan al-Qur'an diantaranya adalah tesis yang ditulis oleh $\mathrm{H}$. Abdullah SA tentang "Kebebasan Beragama dalam Perspektif al-Qur'an (Suatu Pendekatan Tafsir Mawdu'i)". Tesis ini menjelaskan beberapa ayat yang terkait dengan pluralisme agama, lalu menjelaskan pandangan mufassir tentang ayat-ayat tersebut. ${ }^{32}$ Kemudian penelitian saudari Isnatin Ulfa tentang "Perspektif al-Qur'an tentang Pluralisme Agama (Tela'ah Komparatif terhadap Pluralisme Agama dalam Tafsir Jami' al-Bayan dan Tafsir al-Mizan)". Riset ini, merupakan tesis yang ditulis untuk

${ }^{27}$ Howard M. Federspiel, Popular Indonesian Literature of the Qur an (Ithaca, New York: Cornell Modern Indonesia Project, 1994). Karya diterjemahkan ke bahasa Indonesia oleh Tajul Arifin dengan judul Kajian al-Qur'an di Indonesia: dari Mahmud Yunus Hingga Quraish Shihab, (Bandung: Mizan, 1996).

28 Islah Gusmian, Kajian Tafsir Indonesia: dari Hermeneutika Hingga Ideologi (Jakarta: Teraju, 2003).

${ }^{29}$ M. Nurdin Zuhdi, Pasaraya Tafsir Indonesia: dari Kontestasi Metodologi bingga Kontekstualisasi (Yogyakarta: Kaukaba, 2014).

30 Istilah Nusantara ini digunakan karena, beberapa mufassir di Indonesia memang memiliki karakteristik tersendiri yang membedakannya dari tafsir Timur Tengah. Memang, dalam wacana studi Islam dikalangan Islamisists dan orientalist Barat, masyarakat Muslim di Asia Tenggara yang jauh dari the heart land of Islam, Makkah dan Madinah atau Timur Tengah pada umumnya, seringkali dianggap sebagai Islam pinggiran (periferal), sebuah praktik keagamaan yang dianggap jauh dari bentuk "asli". Misalnya, Landon, yang menyebutkan bahwa "Islam di Nusantara hanyalab lapisan tipis diatas kebudayaan local". Lihat K.P. Landon, Southeast Asia; Crossroad of Religion, (Chicago : University ofe Chicago Press, 1949), 134 - 164. Begitu juga Van Leur memberikan justifikasi terhadap asumsi tersebut, yakni dengan mengibaratkan Islam di Asia Tenggara sebagai lapisan tipis yang mudah terkelupas dalam timbunan budaya setempat. J.C. Van Leur, Indonesia Trade and Sosciety, (Den Haag : menyelesaikan studi S2 pada Hukum Islam dalam Ilmu Agama Islam Bidang Konsentrasi Syari'ah IAIN Sunan Ampel Surabaya pada tahun 2003. ${ }^{33}$ Tesis ini membahas tentang ayat-ayat al-Qur'an tentang pluralisme agama secara umum dengan mengambil sudut pandang mufassir. Disamping itu juga menjelaskan titik perbedaan mendasar antara kedua mufassir tersebut dalam memandang ayat-ayat yang dinilai pluralistik.

Islah Gusmian, dalam salah satu tulisannya juga merekomendasikan pentingnya kajian studi Qur'an dengan menimbang aspek kesejarahan dan lolitas sekaligus, baik dari aspek bahasa dan aksara yang dipakai maupun karakteristik lokal yang menyangganya. ${ }^{34}$ Artinya, memahami pluralisme tanpa merefer para ahli tafsir dengan memperhatikan konstruksi sejarah dan kebahasaan, menjadi kurang tepat.

Oleh karena itu, penelitian tentang wacana tafsir pluralisme agama di kalangan mufasir atau ulama di nusantara belum diteliti secara apik. Sehingga penting sekali untuk mengungkap bagaimana para Ulama tafsir di Nusantara, dalam "membaca" aspek paling sensitif dalam agama, yaitu pluralisme. Disadari atau tidak, bidang tafsir memainkan peran penting dalam memberikan

W. Van Hoeeve, 1955), 169. Nah, di era post-modernisme saat ini, istilah "pinggiran" (peripheral) bagi tafsir Nusantarajika diperlawankan dengan "sentral" yang didominasi oleh tafsir Timur Tengah - sudahlah tidak tepat lagi, karena baik tafsir "universal", jika boleh meminjam oposisi binner, maupun tafsir "lokal" itu memiliki urgensi yang sama. Lokalitas tafsir dan metodologi tafsir yang mendasarinya, akan memunculkan orisinalitas dan karakter keindonesian yang perlu diapresiasi, yang tidak selalu ditemukan akarnya dari khazanah tafsir Timur Tengah

31 Izza Rohman, "Karakteristik Kajian al-Quran di Indonesia". Skripsi Jurusan Tafsir Hadis UIN Syarif Hidayatullah Jakarta tahun 2002.

32 H. Abdullah SA, "Kebebasan Beragama dalam Perspektif al-Qur'an (Suatu Pendekatan Tafsir Mawdu'i)", dalam Tesis, (Surabaya: Hukum Islam dalam Ilmu Agama Islam Bidang Konsentrasi Syari'ah IAIN Sunan Ampel Surabaya, 2002)

33 Isnatin Ulfa, "Perspektif al-Qur'an tentang Pluralisme Agama (Tela'ah Komparatif terhadap Pluralisme Agama dalam Tafsir Jami' al-Bayan dan Tafsir alMizan)", dalam Tesis, (Surabaya: Hukum Islam dalam Ilmu Agama Islam Bidang Konsentrasi Syari'ah IAIN Sunan Ampel Surabaya, 2003)

${ }^{34}$ Islah Gusmian, “Tafsir al-Qur'an dan Kekuasaan; Menelusuri Jejak Dealektika Tafsir al-Qur'an dan Praktik Politik Rezim Orde Baru”, dalam AICIS XIV (2014). 


\section{NUSANTARA; Journal for Southeast Asian Islamic Studies}

Vol. 17, No. 1, Juni 2021

gambaran tentang universalitas Islam. Tafsir merupakan manifestasi upaya pemahaman akan alQur'an sebagai pedoman utama umat Islam. Tafsir adalah akar mula seluruh pemahaman dalam bangunan keagamaan Islam. ${ }^{35}$

Penelitian ini, akan mencoba membaca atau membatasi sampel hanya pada beberapa buku tafsir yang ditulis oleh mufassir Nusantara, yaitu Tafsir al-Nur Marab Labid karya Nawawi alBantani; Hamka, Tafsir al-Az̧har; dan Tafsir AlMishbâh. ${ }^{36}$ Serta beberapa pandangan para intelektual muslim Indonesia dalam memaknai beberapa istilah kunci dalam penelitian ini. Misalnya, Nurcholish Madjid, Abdurrahman Wahid, M. Dawam Rahardjo, ${ }^{37}$ Abd. Moqsith Ghazali, ${ }^{38}$ Djohan Effendi, ${ }^{39}$ Jalaluddin Rahmat, ${ }^{40}$ dan Budhy Munawar-Rahman. ${ }^{41}$

Kajian ini, menggunakan metode deskriptif untuk memaparkan penafsiran masing-masing mufassir terhadap beberapa ayat, yang menjadi sampel penelitian. Hal ini penting dilakukan sebelum menggunakan metode komparatif untuk mendapatkan gambaran perbandingan yang sebenarnya antara kedua penafsiran yang dikaji. Setelah sampel dibandingkan, dibutuhkan metode

35 Ulya Fikriyati, "Isu-isu Global dalam Khazanah Tafsir Nusantara: Studi Perbandingan antara Tafsir marah lab'd dan tafsîr almishbâh" dalam Jurnal Șuhuf, Vol. 6, No. 2, 2013 (Jakarta: Lajnah Pentashihan Al-Qur'an Kemenag RI, 2003)

36 Alasan pemilihan ini, sesungguhnya karena alasan pragmatis saja. Pertama, ingin membaca konsep kunci tentang pluralisme agama dari masa dan tempat yang berbeda-beda. Dari sisi latar belakang dan bahasa yang digunakan dalam penulisan tafsirnya. Kedua, Pemilihan ini dimaksudkan untuk melihat dinamika keberagaman tafsir, pergeseran penafsiran dari masa yang berbeda pula.

${ }^{37}$ M. Dawam Rahardjo, Ensiklopedi al-Qur'an: Tafsir Sosial Berdasarkan Konsep-konsep Kunci, Jakarta: Paramadina, 2002).

38 Abdul Moqsith Ghozali, Argumen Pluralisme Agama: Membangun Toleransi Berbasis al-Qur'an (Jakarta: Kata Kita, 2009).

39 Djohan Effendi, Pesan-pesan al-Qur'an: Mencoba Mengerti Intisari Kitab Suci, (Jakarta: Serambi, 2012)

40 Jalaluddin Rahmat, Islam dan Pluralisme; Akblak Qur'an Menyikapi Perbedaan, (Jakarta: Serambi, 2006)

${ }^{41}$ Budhy Munawar Rachman, Argumen Islam untuk Pluralisme, (Jakarta: PT Gramedia Widiasarana Indonesia, 2010)

42 Robert Bogdan \& Steven J. Taylor, Kualitatif, Dasardasar Penelitian, terj. A. Khozin Afandi, (Surabaya: Usaha Nasional, 1993), h. 30 analitis-kritis untuk mencermati sejauh mana penafsiran tersebut saling berkelindan atau saling bertolak belakang demi tercapainya hasil yang diharapkan. Analisa dan kritik ini tentunya tidak dimaksudkan untuk meragukan kapabilitas mufassir dimaksud, akan tetapi lebih pada upaya untuk menilai dengan obyektif sebelum mengamini atau menolak tawaran tafsir yang disuguhkan. Dengan demikian, kajian ini berbentuk kajian kualitatif yang mendasarkan datadatanya, murni pada survey kepustakaan untuk memperoleh gambaran dan penjelasan berupa asumsi-asumsi dasar yang diperoleh dari hasil hipotesis. ${ }^{42}$ Di samping itu, peneliti menjadi alat utama untuk mengumpulkan data sebagaimana yang dikemukakan oleh Lexy J. Moleong dalam kajian kualitatif. ${ }^{43}$

\section{Nalar Pluralisme Agama; Sebuah Eksistensi Tafsir Nusantara}

Kajian tentang pluralisme agama dalam studi agama-agama terbilang baru. ${ }^{44}$ Seratus tahun yang lalu tidak ada seorang pun menyebut atau menulis tentangnya. Yang kita temukan adalah istilah convivencia (bahasa Spanyol untuk co-existence atau

43 Lexy J. Moleong, Metodologi Penelitian: Kualitatif, (Bandung, Remaja Rosdakarya, 2004), h. 165

${ }^{44}$ Dalam catatan Anis Malik Thoha, setidaknya wacana pluralisme agama lahir sektar tahun 60-an. Wacana ini berawal dari agama Kristen yang dimulai setelah Konsili Vatikan II pada permulaan tahun 60-an yang mendeklerasikan "keselamatan umum" bahkan untuk agama-agama di luar Kristen. Gagasan pluralisme ini sebenarnya adalah sebagai upaya peletakan landasan teologis Kristen untuk berinteraksi dan bertoleransi dengan agamaagama lain. Ada juga pendapat bahwa wacana ini lahir dari Rammohan Ray (1773-1833) pencetus gerakan Brahma Samaj dari India, yang semula pemeluk agama Hindu, telah mempelajari konsep keimanan terhadap Tuhan dari sumbersumber Islam, sehingga ia mencetuskan pemikiran Tuhan Satu dan persamaan antar agama. Selain itu, Sri Rama Krishna (1834-1886), seorang mistis Bengali, setelah mengarungi pengembaraan spritual antar agama (passing over) dari agama Hindu ke Islam, kemudian ke Kristen dan akhirnya kembali ke Hindu lagi. Anis Malik Thoha, Tren Pluralisme Agama, (Jakarta: Perspektif, 2005), h. 14. Meskipun sesungguhnya, secara teoretis gagasan tentang pluralisme ini bukanlah sebuah fenomena baru dalam Islam. Budhy Munawar-Rachman, Argumen Islam untuk Pluralisme, Jakarta: PT Grasindo, 2010), 16 
hidup bersama dengan rukun damai), toleration atau tolerance (dari bahasa Latin tolero, tolerare yang artinya membawa, memanggul, menanggung, menahan (to carry, bear, endure, sustain; to support, keep up, maintain). ${ }^{45}$ Di era modern, wacana ini dikembangkan oleh sejumlah pemikir Kristen mutakhir, yaitu Raimundo Panikkar (seorang pastor Katholik kelahiran Sepanyol yang ayahnya beragama Hindu), ${ }^{46}$ Wilfred Cantwell Smith (pengasas dan mantan pengarah Institute of Islamic Studies di McGill University Canada), ${ }^{47}$ Fritjhof Schuon (mantan Kristen yang pergi mengembara keluar masuk pelbagai macam agama), ${ }^{48}$ dan John Hick (profesor teologi di Claremont Graduate School California USA). ${ }^{49}$

Secara etimologi, pluralisme agama, berasal dari dua kata, yaitu "pluralisme" dan "agama". Dalam bahasa Arab diterjemahkan "al-ta'addudiyyah al-diniyyah" dan dalam bahasa Inggris "religious pluralism". Pluralism berarti "jama"' atau lebih dari satu. Martin H. Manser dalam Oxford Learner's Pocket Dictionary: menyebutkan bahwa "Plural (form of a word) used of referring to more than one". ${ }^{50}$ Sedangkan Dalam Kamus Besar Bahasa Indonesia, pluralisme diartikan sebagai hal yang mengatakan jamak atau tidak satu". ${ }^{51}$

Pluralism dalam bahasa Inggris menurut Anis Malik Thoha mempunyai tiga pengertian. Pertama, pengertian kegerejaan: (i) sebutan untuk orang yang memegang lebih dari satu jabatan dalam struktur kegerejaan, (ii) memegang dua jabatan atau lebih secara bersamaan, baik bersifat

45 Lihat misalnya John Locke, A Letter Concerning Toleration (London, 1689; aslinya dalam bahasa Latin berjudul Epistola de Tolerantia) dan Voltaire, Traité sur la tolerance (Paris, 1763). Menurut kamus Oxford English Dictionary, "tolerance is the ability or willingness to tolerate the existence of opinions or behaviour that one dislikes or disagrees with; the capacity to endure continued subjection to something such as a drug or environmental conditions without adverse reaction."

46 Pannikar adalah seorang Spanyol yang beragama Katolik, dan ayahnya beragama Hindu. Ia juga seorang Pastor, yang memperoleh gelar Doktor dalam bidang Sains, Filsafat, dan Teologi. Dalam salah satu tulisannya ia menulis "Saya meninggalkan Kekristenan saya, menemukan diri nsaya sebagai Hindu, dan Kembali menjadi penganut Budha, tanpa berhenti menjadi seorang penganut Kristen". R. Panikkar, The Intra-Religious Dialogue (New York: Paulist Press, 1978), dalam edisi Bahasa Indonesia, buku ini berjudul Dialog Intra Religius, (Yogyakarta: Kanisius, 1994).

${ }^{47}$ Wilfred Cantwell Smith adalah seorang sejarawan agama yang memiliki pengalaman langsung dengan berbagai kegerejaan maupun non kegerejaan. Kedua, pengertian filosofis; berarti system pemikiran yang mengakui adanya landasan pemikiran yang mendasarkan lebih dari satu. Sedangkan ketiga, pengertian sosio-politis: adalah suatu system yang mengakui koeksistensi keragaman kelompok, baik yang bercorak ras, suku, aliran maupun partai dengan tetap menjunjung tinggi aspek-aspek perbedaan yang sangat kerakteristik di antara kelompok-kelompok tersebut. ${ }^{52}$

Bagi Moh. Shofan pluralisme adalah upaya untuk membangun tidak saja kesadaran normatif teologis tetapi juga kesadaran sosial, di mana kita hidup di tengah masyarakat yang plural dari segi agama, budaya, etnis, dan berbagai keragaman sosial lainnya. ${ }^{53}$ Karenanya, pluralisme bukanlah konsep teologis semata, melainkan juga konsep sosiologis. Sementara itu Syamsul Ma'arif mendefinisikan pluralisme adalah suatu sikap saling mengerti, memahami, dan menghormati adanya perbedaanperbedaan demi tercapainya kerukunan antarumat beragama. Dan dalam berinteraksi dengan aneka ragam agama tersebut, umat beragama diharapkan masih memiliki komitmen yang kokoh terhadap agama masing-masing. ${ }^{54}$

Dari beberapa definisi di atas dikatakan bahwa pluralisme merupakan suatu faham tentang kemajemukan yang mana terdapat beraneka ragam ras dan agama yang hidup berdampingan dalam suatu lokasi. Di sini pluralisme tidak hanya sekedar hidup berdampingan tanpa mempedulikan

macam agama ketika mengajar di India di tahun 1941 - 1945. Dia termasuk penggagas berdirinya Islamic Studies McGill University, Canada. di W.C. Smith, The Meaning and End of Religion (London: S.P.C.K., 1978) = Memburu Makna Agama, (Bandung: Mizan, 2004)

${ }^{48}$ F. Schuon, The Transcendent Unity of Religions, tr. Peter Townsend (New York: Pantheon, 1953) = Mencari Titik Temu Agama-Agama (Jakarta: Pustaka Firdaus, 2003)

${ }^{49} \mathrm{~J}$. Hick, Problems of Religious Pluralism (New York: St Martin Press, 1985)

${ }^{50}$ Martin H. Marsen, Oxford Leaner's Pokecet Dictionary, (Oxford: Oxford University, 1999), Third Edition, 329

51 Departemen Pendidikan dan Kebudayaan, Kamus Besar Bahasa Indonesia, (Jakarta: Balai Pustaka, 1999), 691

52 Anis Malik Thoha, Tren Pluralisme Agama, Tinjanan kritis, (Jakarta: Perspektif, 2005), 11

${ }_{53}$ Moh. Shofan, Menegakkan Pluralisme: Fundamentalisme Konservatif di Tubuh Muhammadiyah, (Jakarta: LSAF, 2008), 87

54 Syamsul Ma'arif, Pendidikan Pluralisme di Indonesia, (Jogjakarta: Logung Pustaka, 2005), 17 


\section{NUSANTARA; Journal for Southeast Asian Islamic Studies}

Vol. 17, No. 1, Juni 2021

orang lain. Hal itu membutuhkan ikatan, kerjasama, dan kerja yang nyata. Ikatan komitmen yang paling dalam, perbedaan yang paling mendasar dalam menciptakan masyarakat secara bersama-sama menjadi unsur utama dari pluralisme.

Adapun tentang agama para ahli sosiologi dan antropologi cenderung mendefinisikan agama dari sudut fungsi sosialnya-yaitu suatu system kehidupan yang mengikat manusia dalam satuansataun atau kelompok-kelompok sosial. Sedangkan kebanyakan pakar teologi, fenomenologi dan sejarah agama melihat agama dari aspek substansinya yang sangat asasi-yaitu sesuatu yang sakral.

Dengan demikian, maka akan didapat pengertian pluralisme agama adalah suatu sikap membangun tidak saja kesadaran normatif teologis tetapi juga kesadaran sosial, di mana kita hidup di tengah masyarakat yang plural dari segi agama, budaya, etnis, dan berbagai keragaman sosial lainnya. Selain itu, pluralisme agama juga harus dipahami sebagai pertalian sejati dalam kebhinekaan. Pluralisme tidak juga bisa dimaknai sebagai singkretisme, mencampuradukkan berbagai agama dalam satu keyakinan. Pluralisme menghendaki adanya pengakuan (recognisi) atas adanya berbagai perbedaan. ${ }^{55}$ Pluralisme agama juga bukan ajaran relativisme, bahwa semua kebenaran dalam setiap agama adalah relativ, sehingga akan menggerus keimanan seseorang. Pluralisme agama juga bukan berarti meminta orang untuk berpindah agama, apalagi memaksa orang lain untuk pindah agama. ${ }^{56}$ Oleh karena itu, secara epistemologis, pluralisme agama adalah meyakini bahwa agama yang dipeluknya adalah agama yang paling benar, namun pada saat yang sama, ia juga meyakini bahwa orang lain yang memeluk agama berbeda, memiliki memiliki keyakinan yang sama. ${ }^{57}$

55 Budhy Munawar Rachman, Argumen Islam untuk Pluralisme, Jakarta: PT Gramedia Widiasarana Indonesia, 2010), 74

56 Ibid, 80. Pandangan yang sama dikemukakan oleh Alwi Shihab, bahwa pluralisme agama bukanlah sinkretisme, yakni menciptakan suatu agama baru dengan memadukan unsur tertentu atau sebagian komponen ajaran dari beberapa agama untuk dijadikan bagian integral dari agama tersebut. Lihat Alwi Shihab, Islam Inklusif Menuju Sikap Terbuka, (Bandung: Mizan, 1999), 41-42
Berdasarkan pengertian tersebut, tidak heran jika Nurcholis Madjid memberikan catatan terhadap mereka dalam mengambil sikap pluralisme agama; Pertama, Sikap eksklusif dalam melihat agama lain. Sikap ini memandang agamaagama lain adalah jalan yang salah, yang menyesatkan umat; Kedua, Sikap inklusif.. Sikap ini memandang agama-agama lain adalah bentuk implisit dari agama yang kita yakini; dan Ketiaga, Sikap pluralis. Sikap ini bisa terekspresikan dalam macam-macam rumusan, misalnya pengakuan bahwa "agama-agama lain adalah jalan yang sama-sama sab untuk mencapai kebenaran yang sama", atau "agama-agama lain berbicara secara berbeda, tetapi merupakan kebenaran yang sama sab", atau "setiap agama mengekspresikan bagian penting bagi sebuah kebenaran".

Jadi, pluralisme sesungguhnya adalah sebuah aturan Tuhan (sunnatullab) yang tidak akan berubah, sehingga tidak mungkin dilawan atau diingkari. ${ }^{59}$ Karenanya, pluralisme sebagai desain Tuhan (sunnatullah) harus diamalkan berupa sikap dan tindakan yang menjunjung tinggi sikap beragama yang toleran.

Selanjutnya menurut Nurcholis Madjid yang dikutip Rachman, mengatakan bahwa pluralisme agama tidak dapat dipahami hanya dengan mengatakan bahwa masyarakat kita majemuk, beraneka ragam, berdiri dari berbagai suku dan agama yang justru hanya menggambarkan kesan fragmentasi bukan pluralisme. Pluralisme agama harus dipahami sebagai pertalian sejati kebhinekaan dalam ikatanikatan keadaban (genuine engagement of diversities within the bond of civility). ${ }^{60}$ Sementara itu menurut Alwi Shihab pluralisme yaitu tiap pemeluk agama dituntut bukan saja mengakui keberadaan dan hak agama lain, tapi terlibat dalam usaha memahami perbedaan dan persamaan guna tercapainya kerukunan, dalam klebhinekaan. ${ }^{61}$

${ }^{57}$ Ibid, 94

${ }^{58}$ Nurcholis Madjid, "Mencari Akar-Akar Islam bag Pluralisme Modern: Pengalaman Indonesia", dalam Mark R. Woodward (ed), Jalan Baru, (Bandung: Mizan, 1998), 56

${ }^{59}$ Ibid, 106

60 Budi Munawar Rachman, Islam Pluralis, Jakarta: Paramadina, 2001), 39

${ }^{61}$ Alwi Shihab, Islam Inklusif Menuju Sikap Terbuka , (Bandung: Mizan, 1999), 39 
Dari beberapa definisi menurut para ahli di atas, maka dapat disimpulkan bahwa pluralisme agama merupakan sunnatullah yang tidak akan bisa dirubah atau diingkari. Karenanya pluralisme harus diamalkan berupa sikap saling mengerti, memahami, dan menghormati antarumat beragama guna tercapainya kerukunan umat beragama dan terjalin pertalian sejati kebhinekaan. Bisa juga dipahami bahwa "pluralitas agama" adalah kondisi hidup bersama (koeksistensi) antar agama (dalam arti yang luas) yang berbeda-beda dalam satu komunitas dengan tetap mempertahankan ciri-ciri spesifik atau ajaran masing-masing agama. ${ }^{62}$

Makna tersebut, dalam konteks Indonesia tentu menjadi sangat penting untuk dikembangkan. Dalam sejarah panjang perjalanan bangsa ini, ketegangan intra beragama dan antar umat beragama senantiasa menghiasi perjalanan bangsa ini. Sudah banyak konflik terjadi dalam satu dasawarsa terakhir. Korban tewas dalam konflik sudah tak terhitung. Rumah-rumah peribadatan hancur, sebagian hangus di bakar, sebagian luluh lantak dirobohkan, dan sebagian lainnya rusak oleh amuk massa yang terbakar api kemarahan bersentimen keagamaan. ${ }^{63}$

Salah satu bagian penting dari konsekuensi tata kehidupan global yang ditandai kemajemukan etnis, budaya, dan agama tersebut, adalah membangun dan menumbuhkan kembali semangat ber-tasâmuh dalam masyarakat. Karena pada hakikatnya kita semua adalah sebagai seorang "saudara" dan "sahabat". Bahkan, Islam melalui Al-Qur'an dan Hadistnya juga mengajarkan sikapsikap toleran. Dalam kaitannya yang langsung dengan prinsip inilah Allah, di dalam Al-Qur'an

62 Sebagaimana yang dikemukakan oleh Peter Byrne, profesor di King"s College London UK, bahwa pluralisme agama merupakan persenyawaan tiga tesis, yaitu: Pertama, semua tradisi agama-agama besar dunia adalah sama, semuanya merujuk dan menunjuk sebuah realitas tunggal yang transendent dan suci. Kedua, semuanya sama-sama menawarkan jalan keselamatan. Dan Ketiga, semuanya tidak ada yang final. Artinya, setiap agama mesti senantiasa terbuka untuk dikritik dan ditinjau kembali. Peter Byrne, Prolegomena to Religious Pluralism (London: Macmillan Press, 1995), 191: dalam bahasa aslinya beliau menulis "The three defining theses of our version of [religious] pluralism are as follows: (1) All major religious traditions are equal in respect of making common reference to a single, transcendent reality. (2) All major [religious] traditions are likewise equal in respect of offering some means or other to buman surat Yunus ayat 99, menegur keras Nabi Muhammad SAW ketika beliau menunjukkan keinginan dan kesediaan yang menggebu untuk memaksa manusia menerima dan mengikuti ajaran yang disampaikanya, sebagai berikut:

Dan jikalau Tuhanmu menghendaki, tentulah beriman semua orang yang di muka bumi seluruhnya. Maka Apakah kamu (hendak) memaksa manusia supaya mereka menjadi orang-orang yang beriman semuanya (QS. Yunus: 99)

Ayat di atas telah mengisyaratkan bahwa manusia diberi kebebasan percaya atau tidak. Kaum Nabi Yunus yang tadinya enggan beriman, dengan kasih sayang Allah swt. yang telah memberi peringatan kepada mereka, hingga kaum Yunus yang tadinya membangkang, kemudian atas kehendak mereka sendiri mereka sadar dan beriman. ${ }^{64}$ Demikianlah prinsip dasar Al-Qur'an yang berkaitan dengan masalah pluralisme dan toleransi. Karena Islam menilai bahwa syarat untuk membuat keharmonisan adalah pengakuan terhadap komponen-komponen yang secara alamiah berbeda.

Dengan demikian, menjadi penting untuk melihat dan mendalami bagaimana para ulama memberikan tafsir atas fenomena ini dalam alQur'an. Sebab, hasil riset yang dilakukan oleh Islah Gusmian, ${ }^{65}$ menunjukkan bahwa tafsir Al-Qur'an bukan sekadar menjadi arena pemahaman atas teks Al-Qur'an an sich, tetapi juga menjadi arena penafsir dalam memahami realitas sosial-politik yang terjadi. Dengan demikian, tafsir tidak sekadar bersifat abstrak, transhistoris, melainkan konkret dan secara sosial-politik menjadi sikap penafsir atas realitas sosial-politik yang terjadi. Tafsir tidak

salvation. (3) All major [religious] traditions are to be seen as containing revisable, limited accounts of the nature of this reality: none is certain enough in its dogmatic formulations to provide the norm for interpreting the others."

63 Amirulloh Syarbini, Al-Qur'an dan Kerukunan Hidup Umat Beragama (Bandung: Quanta, 2011), 2-3

${ }^{64}$ Quraish Shihab, Tafsir Al-Misbah Pesan, Kesan dan Keserasian Al-Qur'an (Jakarta: Lentera Hati, 2005), cet 1, vol 6. 164

${ }^{65}$ Islah Gusmian, "Tafsir Al-Qur'an dan Kekuasaan; Menelusuri Jejak Dialektika Tafsir Al-Qur'an dan Praktik Politik Rezim Orde Baru", dalam Paper AICIS 2014, Balikpapan. 


\section{NUSANTARA; Journal for Southeast Asian Islamic Studies}

Vol. 17, No. 1, Juni 2021

sekadar sebagai bentuk media komunikasi yang menangkap dan kemudian menampilkan kembali titah Tuhan dari teks Al-Qur'an, lebih dari itu tafsir juga merupakan sebuah misi praksis-pragmatik dengan membahas isu-isu sosial-politik yang sedang terjadi pada saat tafsir ditulis dan dipublikasikan. Misi yang di dalamnya kemudian lahir gerakan keberpihakan pada hal-hal yang oleh penafsir diyakini benar dan bermanfaat bagi kehidupan umat manusia.

Dalam konteks ini, para ulama nusantara, ketika menafsirkan juga tidak mungkin berada dalam ruang kosong, tanpa memperdulikan sekelilingnya. Artinya, Indonesia yang memiliki tingkat pluralitas yang sangat tinggi, ${ }^{66}$ tidak mungkin dilewati begitu saja oleh para ulama tafsir. Senan, pluralitas itu sesungguhnya menjadi bagian yang tidak terpisah dari kehidupan alam raya ini, dan menjadi modal besar bagi Bangsa Indonesia dalam membangun kehidupan yang penuh dengan kenyamanan dan kedamaian. Masing-masing bisa saling memperkaya dan memberikan perspektif kehidupan yang bermanfaat untuk meningkatkan kualitas kehidupan bersama.

\section{Jejak Pluralisme Agama dalam Tafsir di Nusantara}

Gagasan Tuhan tentang pluralisme agama ini, tercermin dari beberapa Firman yang Dia sampaikan dalam al-Qur'an. Tuhanlah yang menghendaki makhlukNya bukan hanya berbeda dalam realitas fisikal melainkan juga berbeda-beda dalam ide, gagasan, berkeyakinan, dan beragama. Pluralitas ini, tentunya menghendaki adanya hubungan antar umat beragama untuk saling menghargai dan rukun. Kerukunan ini, harus didasari oleh kesadaran hidup bermasyarakat secara plural. Sekaligus disertai dengan keyakinan bahwa pluralitas Agama merupakan Sunnatullah. Karena pluralisme agama dalam Islam itu diterima sebagai kenyataan sejarah yang sesungguhnya diwarnai oleh adanya pluralitas kehidupan manusia itu sendiri, baik Pluralitas dalam berpikir,

66 Sekedar mengulang betapa Indonesia itu "berpelangi" sangat indah, adalah bahwa kekayaan Indonesia tidak saja sebatas pada hasil alam saja, tetapi juga pada ragam suku, bahasa, agama, kepercayaan, dan adat istiadat. Misal untuk kekayaan suku bangsa, Indonesia memiliki ratusan nama suku bahkan ribuan jika dirinci hingga subsukunya. Terdapat lebih dari 300 kelompok etnik atau suku bangsa di berperasaan, bertempat tinggal maupun dalam bertindak.

Al-Qur'an dalam memberikan ide tentang kesadaran terhadap Pluralisme agama terhadap umat manusia, diantaranya tampak dari beberapa firman-Nya sebagai berikut :

Pertama, Mengakui eksistensi perbedaan. Perbedaan ini, tidak hanya pada konteks ras, suku, bahasa, tapi juga agama. "Hai manusia, Sesunggubnya Kami menciptakan kamu dari seorang laki-laki dan seorang perempuan dan menjadikan kamu berbangsabangsa dan bersuku-suku supaya kamu saling kenalmengenal. Sesunggubnya orang yang paling mulia diantara kamu disisi Allah ialah orang yang paling taqwa diantara kamu. Sesunggubnya Allab Maha mengetabui lagi Maha Mengenal (Q.S al Hujurat: 13);

Hamka dalam tafsirnya menguraikan awal penciptaan manusia yaitu berasal dari jiwa yang satu yaitu Adam as kemudian dijadikan istrinya Hawa. perkumpulan kedua insan tersebut mengakibatkan berkumpulnya dua khama yang belum mempunyai warna dan sifat kemudian berwarna menurut iklim buminya, hawa udaranya, letak tanahnya, peredaran musimnya, sehingga timbullah warna dan sifat yang berbeda-beda. Terjadinya berbagai bangsa, suku-suku, warna kulit, bahasa bukan agar bertambah lama bertambah jauh, melainkan supaya mereka saling mengenal, kenal mengenal darimana asal usulnya, darimana pangkal nenek moyangnya, darimana asal keturunan dahulu kala. Dengan demikian dimanapun manusia pergi dia suka mengaji asal usulnya karena ingin mencari pertalian dengan orang lain agar yang jauh menjadi dekat, yang renggang menjadi karib. Kesimpulannya adalah tidak ada perbedaan antara satu dengan yang lainnya sehingga tidak perlu membangkitbangkitkan perbedaan akan tetapi menginsafi adanya persamaan keturunan, karena pada hakekatnya yang membedakan manusia disisi Allah swt hanyalah ketakwaannya. ${ }^{67}$

Indonesia atau tepatnya 1.340 suku bangsa menurut sensus BPS tahun 2010. Sementara agama-agama yang dianut penduduk Indonesia adalah Islam, Kristen, Katolik, Hindu, Budha, dan Konghucu. Di luar enam agama itu, menurut Kementerian Kebudayaan dan Pariwisata tahun 2003, ada 245 agama lokal di Indonesia.

${ }^{67}$ Hamka, Tafsir al-Ažbar, Jilid. XIII..., h. 208-209 
Sementara Abdurrahman Wahid, menyatakan bahwa Islam dengan demikian mengakui perbedaan. Perbedaan itu akan selalu ada pada setiap ciptaan Tuhan.

"Kitab suci al-Qur'an menyatakan, sesungguhnya telah $\mathrm{Ku}$ ciptakan kalian sebagai laki-laki dan perempuan, dan $\mathrm{Ku}$ jadikan kalian berbangsa-bangsa dan bersukusuku bangsa agar kalian saling mengenal (QS al-Hujurat: 13), menunjukkan kepada perbedaan yang senantiasa ada antara laki-laki dan perempuan serta antar berbagai bangsa atau suku bangsa. Dengan demikian, perbedaan merupakan sebuah hal yang diakui Islam, sedangkan yang dilarang adalah perpecahan dan keterpisahan (Tafarruq)" ${ }^{68}$

Menurut Quraish Shihab, ayat di atas menjelaskan bahwa laki-laki dan perempuan setara di hadapan Allah. Mereka mempunyai nilai kemanusiaan yang tidak berbeda. Hanya satu hal yang membedakan mereka jika ingin dibedakan, yaitu kadar ketakwaan dalam masing-masing diri mereka. Karena orang yang paling mulia adalah orang yang memiliki akhlak yang baik. Baik terhadap Allah, dan baik terhadap sesama makhluk-Nya. ${ }^{69}$

Adapun menurut Syeikh Nawawi, sesungguhnya tidak ada tujuan lain dari penciptaan manusia menjadi berbangsa-bangsa dan bersukusuku kecuali agar mereka bisa saling mengenal sebagai sesama manusia yang diturunkan dari satu bapak. Oleh karena itu, diperintahkan bagi setiap manusia untuk tidak membangga-banggakan keturunan dan nasabnya. Sesungguhnya yang paling mulia di hadapan Allah adalah mereka yang bertakwa. $^{70}$

Pada intinya bahwa ayat ini menjelaskan bahwa Allah swt telah menciptakan makhluknya, laki-laki dan perempuan, dan menciptakan manusia berbangsa-bangsa, untuk menjalin hubungan yang baik. Kata ta'arafu pada ayat ini maksudnya bukan hanya berinteraksi tetapi berinteraksi positif. Karena itu setiap hal yang baik dinamakan dengan ma'ruf. Dijadikannya makhluk

68 Abdurrahman Wahid, Islamku Islam Anda Islam Kita, (Jakarta: The Wahid Institute, 2006), 134

${ }^{69}$ Quraish Shihab, Tafsîr Al-Mishbâh ..., vol. 13, 262

${ }^{70}$ Mu¥ammad Nawawî al-Jawi, Marah Labid..., jilid. 2, dengan berbangsabangsa dan bersuku-suku adalah dengan harapan bahwa satu dengan yang lainnya dapat berinteraksi secara baik dan positif. Lalu dilanjutkan dengan ayat... inna akramakum 'indallahi atqakum... maksudnya, bahwa interaksi positif itu sangat diharapkan menjadi prasyarat kedamaian dibumi ini. Namun, yang dinilai terbaik di sisi Allah adalah mereka itu yang betul-betul dekat kepada Allah. $^{71}$

Dalam konteks agama-agama, al-Qur'an menyatakan dengan tegas bahwa "Sekiranya Allah menghendaki, niscaya kamu dijadikan-Nya satu umat (saja), tetapi Allab bendak menguji kamu terbadap pemberian-Nya kepadamu, maka berlomba-lombalah berbuat kebajikan. hanya kepada Allah-lah kembali kamu semuanya, lalu diberitabukan-Nya kepadamu apa yang telah kamu perselisibkean itu." (QS. Al-Maidah: 48); Ayat lainnya, "Dan kalau Allah menghendaki, niscaya dia menjadikan kamu satu umat (saja), tetapi Allah menyesatkan siapa yang dikehendaki-Nya dan memberi petunjuk. kepada siapa yang dikehendaki-Nya. (QS. An Nahl: 93).

Muhammad ibn Umar Nawawi al-Jawi alBantani, dalam Marah al-Labid menjelaskan sebagai berikut:

(wa ma kana al-nnasu illa umatan wabidah, dan manusia itu dahulu tiada lain kecuali satu umat) Maknanya: mereka berada dalam agama Islam dari masa Adam sampai peristiwa pembunuhan Habil oleh Qabil. (fa-kbtalafu) bahwa sebagian mereka menjadi kafir dan sebagian yang lainnya tetap dalam agama Islam. (wa lau la kalimatun sabaqat min Rabbika) Maknanya: kalau bukan karena Allah Ta'ala telah memberi tahu bahwa beban kewajiban tetap berada di pundak hambaNya meskipun mereka kafir, (laqudhiya bainabum, niscaya diputuskan hukumannya di antara mereka) dengan menyegerakan hisab dan azab karena kekafiran mereka, dan manakala hal itu menjadi sebab hilangnya beban kewajiban (taklif) dan melanggengkannya lebih baik,

71 Muhamad Arif Mustofa, "Kerukunan Umat Beragama (Studi Analisis Tentang Non Muslim, Ahlul Kitab \& Pluralisme)", dalam Jurnal MIZANI VOL. IX, NO.1, Februari 2015. 


\section{NUSANTARA; Journal for Southeast Asian Islamic Studies}

Vol. 17, No. 1, Juni 2021

maka Allah menunda balasannya sampai hari Akhirat. ${ }^{72}$

Ayat ini, menegaskan akan kemestian keragaman dalam beragama. Menurut M. Qurais Shihab memang dalam dunia ini banyak kelompok yang berbeda-beda atau bertolak belakang tetapi itu adalah kehendak Allah.

"...Seandainya dia menghendaki, dia akan menjadikan kamu seia sekata, tetapi itu tidak dikehendakinya dan dia akan memutuskan perbedaan itu kelak diakhirat bukan di dunia ini. Jadi jangan jadikan perbedaan sebagai dalih tidak menepati janji walaupun dengan kelompok yang berbeda Aqidah dan kepercayaan dengan kamu. Dan jikalau Allah menghendaki namun tidak tidak dikehendakinya, Niscaya dia menjadikan kamu satu umat saja. ${ }^{73}$

Hamka di dalam Tafsir Al-Az̧har juga mengatakan bahwa dalam ayat tersebut Allah mengatakan bahwa sesungguhnya:

Ia kuasa untuk menjadikan syariat manusia itu satu saja sejak zaman Adam sampai Muhammad. Namun Allah tidak menjadikan demikian, manusia tidak hanya diberi insting, tetapi juga diberi akal. Maka di ujilah manusia dengan akal tersebut untuk menyesuaikan hidupnya dalam alam sekeliling dan dianjurkan untuk menggunakan akal tersebut untuk berlomba-lomba melakukan perbuatan baik. Dengan diberinya kebebasan berpikir untuk menuju kebaikan, maka sudah tentu terdapat perselisihan pendapat dan ijtihad. ${ }^{74}$

Dari uraian tersebut di atas, menunjukkan bahwa proses penciptaan manusia di alam semesta bertujuan untuk dapat saling mengenal dan memahami satu sama lain, dengan menjauhkan diri dari perasaan fanatisme (ta'ashub); baik terhadap golongan, partai politik, suku, ataupun bangsa. ${ }^{75}$ Oleh karena itu, memahami pluralitas perbedaan itu, dengan menginsafinya sebagai sarana berinteraksi dan berdialog antarsesama manusia

${ }^{72}$ Muhammad ibn Umar Nawawi al-Jawi al-Bantani, Marah al-Labid li Kasyfi Ma'na al-Qur'an al-Majid, (Beirut: Dar al-Kutub al-'Ilmiyah, 1997), 482 - 483.

${ }^{73}$ M. Qurais Shihab. Membumikan al-Qur'an: Mukjizat Al-Qur'an. Cet. I. (Bandung: PT Mizan Pustaka, 2007), 710711 dan sebagai ujian dan sarana manusia dalam berlomba menuju kebaikan dan prestasi.

Kedua, Memberinya hak untuk hidup berdampingan saling menghormati pemeluk agama lain tanpa ada unsur kecurigaan. Dalam alQur'an, Allah mengatakan "Dan janganlah kamu memaki sembahan-sembahan yang mereka sembah selain Allah, Karena mereka nanti akan memaki Allah dengan melampaui batas tanpa pengetahuan... (QS. Al-An'am: 108). Ayat ini ditujukan kepada kaum Muslimin yakni, dan janganlah kamu wahai kaum muslimin memaki sembahan-sembahan, seperti berhalaberhala yang meraka sembah selain Allah karena jika kamu memakinya, maka akibatnya mereka akan memaki pula Allah dengan melampaui batas atau secara tergesah-gesah tanpa berfikir dan tanpa pengetahuan. Menghindari kekerasan dan memelihara tempat-tempat beribadah umat beragama lain Qs. Al.Hajj : 40.

Oleh karena itu, bagi Hamka, umat Islam juga dilarang mencaci-maki sesembahan yang disembah oleh orang Kafir karena itu akan menyebabkan mereka akan balik memaki Allah dengan tanpa ilmu. Lebih baik ditunjukkan saja kepada mereka alasan yang masuk akal bagaimana keburukan menyembah berhala atau tuhan selain Allah. ${ }^{76}$ Sedangkan menurut M. Quraish Shihab, ayat ini ingin memberikan bimbingan kepada kaum muslimin untuk tidak melakukan hal-hal yang menyangkut mencaci Tuhan-Tuhan non muslim maupun penganut agama selain Allah swt, karena boleh jadi mereka berbalik memaki Allah dengan melebihi batas kewajaran. ${ }^{77}$

Maka dari itu ayat ini mengandung dua konsep yaitu wujud dan dampak, dampaknya yaitu mereka akan melakukan hal yang sama bahkan lebih seperti apa yang dilakukan oleh orang muslim ketika ketika keyakinan mereka dihina ataupun dimaki bukan saja itu dampak yang akan terjad bila melakukan tindakan memaki atau pelecehan terhadap penganut agama lain antara lain yaitu renggangnya suatu hubungan dalam kehidupan beragama dan toleransi kehidupan beragama

\footnotetext{
${ }^{74}$ Hamka, Tafsir Al-Az̧ar......, 349

${ }^{75}$ Nasarudin Umar, Deradikalisasi, 316

${ }^{76}$ Hamka, Tafsir Al-Azhar Juz VII-VIII (Jakarta : Pustaka Panjimas, 1984), hlm. 409

77 M. Quraish Shihab, Tafsir al Misbah: Pesan dan Keserasian Al-Qur'an Vol. 3 h. 606
} 
adalah suatu upaya perilaku dan tindakan sesuai dengan nilai-nilai agama yang menekankan kerukunan hidup beragama serta menjaga toleransi dalam masyarakat. Pada hakikatnya muslim ataupun non muslim telah dilarang melakukan celaan atau hinaan terhadap suatu keyakinan, ras, suku, serta budaya apalagi jika dilihat dalam konteks bangsa Indoesia yang menganut paham kebhinekaan (Berbeda tapi satu). Jika dalam kehidupan beragama saling menghina atau mencela maka akibatnya dalam kehidupan tidak ada rasa perdamaian, rasa toleransi, rasa aman, serta terpecah belah suatu hubungan yang mengakibatkan peperangan antar agama ataupun berujung pada pertikaian antar umat beragama.

Konsekuensi dari kesadaran pemahaman tersebut adalah munculnya kesadaran baru tentang relasi antara agama ini. Allah mengatakan "Katakanlah, "Wahai, Ablul Kitab! Marilab kemari kepada kalimat yang sama di antara kami dan kalian, yaitu janganlah kita menyembah melainkan kepada Allah, dan janganlah kita menyekutukan sesuatu dengan Dia, dan jangan menjadikan sebagian dari kita akan sebagian yang lain menjadikan Tuban-Tuban selain Allah." Maka jika mereka berpaling, hendaklah kamu katakana, "Saksikanlah olehmu bahwasannya kami ini adalab orang-orang Islam.” (Q.S. Ali Imrân [3]: 64)

Dalam Tafsir al-Azhar, disebutkan bahwa ayat ini berkaitan "Betapapun pada kulitnya kelihatan kita ada perbedaan, ada Yabudi, ada nasrani, dan ada Islam, namun pada kita ketiganya tedapat satu kalimat yang sama, satu kata yang menjadi titike pertemuan kita. Yaitu "Janganlah menyembah melainkan kepada Allab," sekiranya saudara-saudara sudi kembali kepada satu kalimat itu, niscaya tidak akan ada selisih kita lagi". ${ }^{78}$ Bahkan menurut keterangan Hamka, ayat ini jugalah yang dijadikan Nabi Muhammad saw, sebagai alasan untuk mengirim surat kepada Heraclius Raja Romawi Syam. ${ }^{79}$

${ }^{78}$ Hamka, Tafsir Al-Az̧bar, Jilid I, 649.

${ }^{79}$ Ibid, 652.

${ }^{80}$ M. Quraish Shihab, Tafsir Al-Mishbah, volume 2, 141

${ }^{81}$ Pemaknaan Islam ini penting dan perlu digunakan pada makna generiknya, yaitu kepasrahan penuh atau totalitas ketundukan pada Tuhan, tanpa kemungkinan menberi peluang untuk melakukan sikap dasar serupa
Sedangkan M. Quraish Shihab memberikan penjelasan terkait dengan ayat tersebut adalah sebagai berikut:

"Kalau kalian berpaling dan menolak ajakan ini,, saksikanlah dan akuilah bahwa kami adalah orang-orang muslim, yang akan melaksanakan secara teguh apa yang kami percayai. Pengakuan kalian akan eksistensi kami sebagai muslim, walau kepercayaan kita berbeda menuntut kalian untuk membiarkan kami melaksanakan tuntutan ajaran agama kami. Karena kamipun sejak dini telah mengakui eksistensi kalian tanpa kami percaya apa yang kalin percayai. Namun demikian, kami mempesilahkan kalian melaksanakan kalian melaksanakan ajaran agama kalian.." 80

Proposisi tersebut, diperkuat oleh pandangan para mufasir bahwa semua ajaran yang dibawa oleh para Nabi dan Rasul, merujuk pada satu ajaran, yaitu Islam. ${ }^{81}$ Artinya, pada dasarnya semua agama yang lahir di alam semesta ini, wujud dari islam. Sebagaimana penafsiran Nurcholish Madjid sebagai berikut;

"Pada dasarnya seluruh agama adalah sama, walaupun memiliki jalan yang berbeda-beda untuk tujuan yang sama dan satu. Dalam alQuran misalnya, diilustrasikan bahwa semua Nabi dan rasul itu adlah Muslim. Semua agama para Nabi adalah Islam. Sehingga Islam par execellence ini adalah bentuk terlembaga dari agama yang sama itu." $" 82$

Abdul Munir Mulkhan juga menulis bahwa jika semua agama memang benar sendiri, perlu diyakini bahwa surga Tuhan juga satu namun memiliki banyak pintu. Akan ada kamar di surga bagi pemeluk Islam, Konghuchu, Budha dan lainlain. ${ }^{83}$ Pendapat serupa diungkapkan pula oleh Abdul Moqsith Ghazali. ${ }^{84}$

Begitu pula, menurut Tarjuman al-Mustafid, Abdur Ra'uf as-Sinkili memberikan penafsiran atas

sesuatu apap pun selain dari pada-Nya. Lihat Syamsul Arifin, Studi Islam Kontemporer, 237.

82 Nurcholis Majid, Islam Doktrin dan Peradaban (Jakarta, Paramadina, 2008), 421.

83 Abdul Munir Mulkhan, Ajaran dan Jala Kematian Syekh Siti Jenar (Yogykarta, Kreasi Wacana, 2008), 44.

84 Abdul Moqsith Ghazali, Argumen Pluralisme Agama (Jakarta, Kata Kita, 2009), 240-421. 
ayat 10 surat Yunus tentang keniscayaan akan pluralitas penciptaan, sebagai berikut:

"Dan tiada ada manusia itu daripada masa Adam datang kepada masa Nuh melainkan atas agama Islam, kemudian maka bersalahsalahan mereka itu. Dan jikalau tiada sudah hukum dahulu daripada Tuhanmu mengemudiankan balas kepada hari kiamat niscaya dihukumkan antara segala manusia di dalam dunia pada yang di dalamnya bersalahsalahan mereka itu". ${ }^{85}$

Hamka dalam hal ini, juga memberikan pernyataan yang sangat lugas, bahwa;

Umat manusia pada dasarnya adalah satu. Begitu pula hanlnya, agama-agama ini sebenarnya satu. Kandungan pesan semua nabi tidak berubah, meskipun perubahan terjadi dalam bahasa. Syariat dan cara pelaksanaannya bisa saja berbeda karena perubahan waktu dan tempat. Namun intisari dari maksud agama yang sebenarnya hanyalah satu, pengakuan akan keesaan Tuhan. ${ }^{86}$

Hamka sangat menenakankan bahwa agama yang dibawa sejak Nabi Adam hingga Nabi Muhammad, termasuk Musa dan Isa, tidak lain adalah agama Islam, yang berarti kepasrahan dan ketundukan kepada Tuhan, dan beriman semata kepada-Nya. ${ }^{87}$

Inilah makna kesataraan dalam beragama. Dengan memaknai agama adalah proses menemukan kebenaran universal pada setiap agama, maka semua orang umat beragama akan bertemu pada titik kesamaan ini. Dalam konteks kebangsaan Indonesia, pokok pangkal dari kebenaran universal yang tunggal ini adalah yang termaktub pada sila pertama dari Pancasila, yaitu Ketuhanan Yang Maha Esa, atau tawhid, mengesakan Allah,

Ketiga, Larangan adanya unsur paksaan dalam beragama. Al-Qur'an tidak pernah membenarkan adanya paksaan dalam memeluk suatu agama, karena hal merupakan hak-hak manusia yang memang menjadi perhatian serius dari setiap pesan-pesan (message) al-Qur'an.

\footnotetext{
85 Abdur Ra'uf as-Sinkili, al-Tarjuman al-Mustafid, h. 210

${ }^{86}$ Hamka, Tafsir al-Az̧ar, jilid I, 184

${ }^{87}$ Ibid, 135. Lihat juga Mun'im A. Sirri, Polemik Kitab Suci, (Jakarta: Gramedia, 2013), 131
}

Beberapa ayat al-Qur'an, yang menegaskan hal itu adalah; "Tidak ada paksaan untuk (memeluk) agama (Islam); sesunggubnya telah jelas jalan yang benar daripada jalan yang sesat. Karena itu barangsiapa yang ingkar kepada Thaghut dan beriman kepada Allah, maka sesungguhnya ia telah berpegang kepada bubul tali yang amat kuat yang tidak akan putus. Dan Allah Maha Mendengar lagi Maha Mengetabui" (QS. Al-Baqarah : 256). Pernyataan tentang tidak ada paksaan untuk memeluk agama ini, kemudian dikuatkan oleh ayat al-Qur'an yang membahas tentang bagaimana seharusnya sikap seorang muslim jika ada umat non-muslim yang mengajaknya untuk bertukar keyakinan, yaitu surat Al-Kafir $\mu n$ : ayat 1-6.

Dalam menafsiri Surat al-Baqarah ayat 256, Hamka mengemukakan asbabun nuгul yang diriwayatkan oleh Abu Dawud, an-Nasa'i, Ibnu Mundzir, Ibnu Jarir, Ibnu Abu Hatim, Ibnu Hibban, Ibnu Mardawaihi, dan al-Baihaqi dari Ibnu Abbas dan beberapa riwayat lainnya. Hamka menguraikannya sebagai berikut;

Dalam hadits tersebut dikisahkan bahwa penduduk Madinah sebelum memeluk agama Islam, merasa bahwa kehidupan orang Yahudi lebih baik dari kehidupan mereka sebab mereka masih jahiliyah. Sebab itu, di antara mereka ada yang menyerahkan anaknya kepada orang yahudi untuk dididik dan setelah besar mereka menjadi Yahudi. Ada pula perempuan Arab yang tiap beranak mati maka kalau ia beranak lagi, lekas-lekas diserahkan kepada orang Yahudi. Dan oleh orang Yahudi anak-anak tersebut diyahudikan. Selanjutnya, orang Madinah menjadi Islam, dan menjadi kaum Anshar. Maka setelah Rasulullah pindah ke Madinah, dibuatlah perjanjian dengan kabilah-kabilah Yahudi yang tinggal di Madinah. Akan tetapi dari bulan-ke bulan, tahun ke tahun, perjanjian itu mereka ingkari, baik dengan cara halus aaupun kasar. Akhrinya, terjadilah pengusiran terhadap Yahudi Bani Nadhir yang telah didapati telah dua kali hendak membunuh Nabi. Namun ditengah-tengah Bani Nadhir itu ada anak orang Anshar yang telah menjadi Yahudi.

\footnotetext{
${ }^{88}$ Nurcholish Madjid, Islam, Doktrin Peradaban, (Jakarta: Paramadina, 1992), 180
} 
Ayah anak itu memohon kepada Nabi supaya anak itu ditarik kepada Islam, kalau perlu dengan paksaan. Si ayah yang telah memeluk Islam tidak sampai hati melihat anaknya yang menjadi Yahudi. "belahan diriku sendiri akan masuk neraka, ya Rasulallah!" kata orang Anshar itu. Di waktu itulah turun ayat ini. ${ }^{89}$

Sedangkan Quraish Shihab ketika menafsirkan Al-Baqarah : 256, beliau menjelaskan terlebih dahulu hubungan dengan ayat sebelumnya yaitu ayat al-Kursiy, yang menerangkan siapa Allah dan kewajaran-Nya untuk disembah, serta keharusan mengikuti agama yang ditetapkan-Nya, serta jelas pua Dia memiliki kekuasaan yang tidak terbendung, maka bisa jadi ada yang menduga bahwa hal tersebut dapat menjadi alasan bagi Allah untuk memaksa makhluk menganut agama-Nya, apalagi dengan kekuasaan-Nya yang tidak terkalahkan itu. ${ }^{90} \mathrm{Hal}$ ini, Allah menghendaki agar setiap orang merasakan kedamaian. Agama-Nya dinamai Islam, yakni damai. Kedamaian tidak dapat diraih kalau jiwa tidak damai. Paksaan menyebabkan jiwa tidak damai, karena itu tidak ada paksaan dalam menganut keyakinan agama Islam. $^{91}$

Suatu hari, kota Madinah kedatangan rombongan pedagang dari Syam. Mereka adalah saudagar-saudagar yang biasa memasok barang dagangan ke Makkah dan Madinah. Para saudagar itu beragama Kristen. Sambil berdagang mereka melakukan tugas misionaris (dakwah) kepada penduduk di kawasan Jazirah Arabia. Kedua anak Abû al-Husein kerap membeli minyak dan kebutuhan lainnya dari para pedagang itu. Seperti biasanya, para pedagang itu mengkampanyekan agama mereka kepada para pedagang di Madinah, termasuk kepada kedua anak Abû al-Husein. Karena khawatir tidak mendapat pasokan barangbarang dari para saudagar itu, kedua anak tersebut akhirnya memutuskan diri masuk Kristen. Mereka dibaptis oleh para saudagar itu, sebelum mereka kembali ke Syam. Mendengar kedua anaknya masuk Kristen, Abû al-Husein sangat terpukul. Ia pun mendatangi Nabi dan mengadukan perkara yang menimpanya itu. Lalu, turunlah ayat terkenal

\footnotetext{
${ }^{89}$ Ibid

${ }^{90}$ M. Quraish Shihab. Tafsir Al-Mishbah, h. 551-552.

91 Ibid. h. 551-552.

92 Muhammad Nawâwî al-Jawî, Marah Labib, jilid I (Kairo: Dâr al-Kutub, 1976), h. 74
}

"lâ ikrâha fî al-dîn..." tidak ada paksaan dalam beragama. (Q.S. al-Baqarah/2: 256). Demikian pandangan Muhammad Nawâwî al-Jawî, dalam Marah Labib. ${ }^{92}$

Dalam menafsirkan surat al-Kafirun. Hamka menulis: soal akidah, di antara taubid mengesakan Allah, sekali-sekali tidaklah dapat dikompromikan atau dicampuradukekan dengan syirik. Taubid kalau telah didamaikan dengan syirik, artinya kemenangan syirik.. ${ }^{93}$ Oleh sebab itu, bagi Hamka "....ibadahmu itu bukan ibadah dan tubanmu itu pun bukan tuban. Untuke kamulab agamamu. Jangan pula aku diajak menyembah yang bukan tuban itu. Dan untuk akulah agamaku, jangan sampai hendak kamu campur adukekan dengan apa yang kamu sebut agama itu". ${ }^{4}$

Syeikh Nawawi menafsirkan ayat ke-enam tersebut dengan menjadikannya penguat dan keputusan akhir dari ayat sebelumnya yang artinya:

"Sesungguhnya agamamu, yaitu agama yang syirik, hanya berlaku bagimu, dan demikian juga agamaku, yaitu agama tauhid, juga hanya berlaku bagiku. Sesungguhnya aku adalah seorang Nabi yang diutus kepada kalian untuk menyeru kepada kebenaran dan keselamatan, dan jika kalian tidak menerima seruan tersebut, dan tidak pula mengikutinya, maka tinggalkanlah aku dan jangan mengajakku kepada kesyirikan.... Dikatakan juga bahwa makna ayat ini adalah: bagi kalian hukuman dari Tuhanku, dan bagiku hukuman dari berhala-berhala kalian. Akan tetapi berhalaberhala kalian adalah benda mati, dan aku sama sekali tidak takut atas hukuman mereka"

Menurut M. Qurais Shihab, QS. Al-Kafirun ayat ke enam di atas, merupakan pengakuan eksistensi secara timbal balik, bagi kamu agama kamu dan bagiku agamaku. Sehingga dengan demikian masing-masing pihak dapat melaksanakan yang dianggapnya benar dan baik, tanpa memutlakkan pendapat kepada orang lain tetapi sekaligus tanpa mengabaikan keyakinan masing-masing. 95 Kemudian Quraisy Shihab melanjutkan dengan mengutip QS. Sabae [34] ayat: 24-26, dan menyatakan bahwa ayat tersebut menerangkan

\footnotetext{
${ }^{93}$ Hamka, Tafsir Al-Az̧har, jilid IX h. 679.

94 Ibid, h. 679-680

${ }^{95}$ M. Quraish Shihab, Vol. 15, 581-582.
} 


\section{NUSANTARA; Journal for Southeast Asian Islamic Studies}

Vol. 17, No. 1, Juni 2021

Nabi Muhammad tidak diperintahkan menyatakan apa yang di dalam keyakinan tentang kemutlakan kebenaran ajaran Islam, tetapi justru sebaliknya, kandungan ayat tersebut bagaikan menyatakan: Mungkin kami yang benar, mungkin pula kamu; mungkin kami yang salah, mungkin pula kamu. Kita serabkan saja kepada Tuban untuk memutuskannya. ${ }^{96}$

Tidak dibolehkannya pemaksaan agama tersebut, menjadi jelas posisi manusia yang diberikan kebebasan untuk menentukan sikap dan keyaknan beragamanya. Pemaksaan dalam beragama menjadi tidak dibenarkan. ${ }^{97}$ Sehingga kebebasan beragama merupakan prinsip dasar ajaran Islam. Memeluk agama sejatinya merupakan keyakinan mendalam terhadap setiap ajaran yang ditetapkan oleh agama itu sendiri. Bahkan setiap orang punya hak yang sama untuk menentukan sendiri agamanya. Ketika Rayhanah binti Zaid, salah seorang budak Nabi Muhammad, ${ }^{98}$ diminta oleh Nabi untuk ber-Islam, namun Rayhanah menolak dengan tetap memilih agama Yahudi, maka Nabi tidak marah dan tidak memaksa Rayhanah masuk Islam.

Keempat, pengakuan keselamatan pada masing-masing agama. Apakah surga hanya milik umat beragama tertentu saja? Al-Qur'an dengan tegas menjelaskan sebagai berikut: Mereka (sebagian Yabudi dan Nasrani) berkata; "Sekali-kali tidak akan masuk surga kecuali orang-orang Yabudi atau Nasbrani". Demikian itu hanyalah angan-angan kosong mereka saja. Katakanlah "tunjukkanlah bukti kebenaranmu jika kamu adalah orang yang benar". Babkan barangsiapa yang menyerabkan diri kepada Allah, sedang ia berbuat kebajikan, maka baginya pahala di sisi Tubannya dan tidak ada kekhawatiran terbadap mereka dan tidak (ada)

\section{${ }^{96}$ Ibid, h. 582.}

${ }^{97}$ Muhammad Bâqir al-Nashirî, ahli tafsir asal Iran, menjelaskan bahwa ada lima pendapat berkaitan dengan Q.S. al-Baqarah/2: 256. Pertama, pelarangan itu hanya khusus kepada Ahl al-Kitab (Yahudi dan Kristen). Kedua, pelarangan itu ditujukan kepada semua orang non-Islam. Ketiga, orangorang yang masuk Islam setelah perang tidak merasa dipaksa, tetapi mereka masuk secara sukarela. Keempat, ayat tersebut ditujukan hanya kepada kaum Anshâr. Kelima, pilihan beragama bukanlah sesuatu yang dipaksakan dari Allah, tapi ia merupakan pilihan manusia, karena persoalan agama adalah persoalan keyakinan individual. Muhammad Bâqir alNashirî, Mukhtashar Majma' al-Bayân (Kairo: Dâr alMa'rifah, t.t), h. 169. Dan Rasyid Ridha lebih cenderung setuju dengan pendapat kelima. Yakni, bahwa maksud ayat "lâ ikrâha fî̀ al-dîn..." adalah bahwa tidak boleh ada pula mereka bersedih hati”. (QS. Al-Baqarah: 111 112).

M. Nawawi al-Jawi menjelaskan bahwa klaim yang disebut oleh al-Qur'an itu adalah orang Yahudi Madinah dan Nashrani Najran. Lebih lanjut, ia menyatakan;

Orang-orang Yahudi Madinah berkata bahwa yang masuk surga hanya orang-orang Yahudi. Tak ada agama selain Yahudi. Orang-orang Nashrani Najran juga berkata bahwa yang masuk surga hanyalah orang-orang Nashrani. Tak ada agama selain Nashrani. Sama sekali tidak. Selain mereka masuk surga. Yaitu orang-orang yang tulus mepada Allah dengan tidak menyekutukan-Nya, berbuat baik dalam semua tindakannya. Baginya adalah pahala telah dijanjikan Tuhan-Nya di dalam surga. ${ }^{99}$

Menurut Hamka, yang dimaksud sabi'in adalah orang yang keluar dari agamanya yang asal dan masuk ke dalam agama lain, sebab hal ini pernah dituduhkan kepada Rasulullah ketika Nabi menginkari menyembah berhala sebagaimana kebiasaan kaum Quraisy sehingga Rasulullah di sebut sabi. ${ }^{100}$ Sedangkan Abd Rauf, menyebut Shabi'in sebagai suatu tha'ifah dari agama Nashara atau Yahudi. ${ }^{101}$ Menurut riwayat para ahli tafsir golongan sabiin pada mulanya adalah golongan orang-orang yang memeluk agama Nasrani lalu mendirikan agama sendiri. Menurut penyelidikan mereka masih berpegan teguh pada cinta kasih ajaran al Masih, akan tetapi mereka pun mulai menyembah malaikat dan percaya akan pengaruh bintang-bintang. ${ }^{102}$

“... Umat Yahudi, Nasrani dan sabi'in tidak ada perbedaan apabila memenuhi persyaratan

pemaksaan kepada seseorang untuk menentukan agamanya. Pesan ini bersifat umum ('am) dan ditujukan bukan hanya untuk kaum tertentu saja. Muhammad Rasyid Ridha, Tafsîr al-Qur'ân al-Hakim, juz III (Beirut: Dâr al-Fikr, 1964), h. 31.

${ }^{98}$ Dalam catatan Ibn Kastir, budak perempuan Nabi Muhammad itu ada 24 orang. Diantara budak-budak nabi tersebut ada yang beragama Yahudi, yaitu Rayhanah binti Zaid dan beragama Nashrani, yaitu al-Qibtiyah. Lihat Ibn Katsir, al-Bidayat wa al-Nihayat, jilid III, 307 - 313.

${ }_{99}$ Muhammad ibn Umar Nawawi al-Jawi al-Bantani, Marah al-Labid li Kasyfi Ma'na al-Qur'an al-Majid, Juz I, (Beirut: Dar al-Kutub al-'Ilmiyah, 1997), 30

100 Hamka, Tafsir al Azhar, Jilid. 1,..., h. 264

101 Abdur Ra'uf al-Sinkili, Tarjuman al-Mustafid,

(Mumbai: Nelini Berindra, Ahmad Abad, 1951), 12.

102 Hamka, Tafsir al Azhar, Jilid. 1,..., h. 264 
yang telah ditetapkan yaitu iman dan beramal shaleh. Syarat pertama belum cukup apabila belum dipenuhi syarat yang kedua yaitu beramal shaleh atau berbuat pekerjaanpekerjaan yang baik yang berfaedah dan bermanfaat bagi dirinya sendiri maupun masyarakat..."103

Selain itu, secara progresif al-Qur'an jutru mengakui akan adanya doktrin penyelamatan (salvafic efficacy) umat lain dalam hubungannya dengan lingkup monoteisme yang lebih luas. AlQur'an menjelaskan dalam surat al-Baqarah/2: 62 dan alMaidah/5: 69, sebagai berikut: Ayat lainnya adalah Sesungguhnya orang-orang mukmin, orang-orang Yabudi, orang-orang Nasrani dan orang-orang Shabiin, siapa saja diantara mereka yang benar-benar beriman kepada Allah, hari kemudian dan beramal saleh, mereka akan menerima pabala dari Tuban mereka, tidak ada kekhawatiran kepada mereka, dan tidak (pula) mereka bersedih hati (QS. Al-Baqarah: 62); Ditegaskan lagi pada ayat yang lain "Sesunggubnya orang-orang Mu'min, orang-orang Yabudi, orang-orang Shabiin, dan orang-orang Nashrani, siapa saja (di antara mereka) yang benar-benar beriman kepada Allah, hari kemudian, dan beramal saleh, maka tidak ada kekhawatiran terhadap mereka, dan tidak (pula) mereka bersedih hati." (QS alMaidah/5: 62).

Jika diperhatikan dengan seksama, maka jelas bahwa dalam ayat itu [Q.S. 2:62] tidak ada ungkapan agar orang Yahudi, Nasrani, dan orangorang Sabi'ah beriman kepada Nabi Muhammad. Dengan mengikuti bunyi harafiah ayat tersebut, maka orang-orang beriman yang tetap dalam keimanannya, orang-orang Yahudi, Nasrani, dan Sabi'ah yang beriman kepada Allah dan hari Akhir serta melakukan amal saleh-sekalipun tak beriman kepada Nabi Muhammad, maka mereka akan memperoleh balasan dari Allah. Pernyataan agar orang-orang Yahudi, Nasrani, dan Sabi'ah beriman kepada Nabi Muhammad adalah pernyataan para mufasir dan bukan ungkapan Alquran. Muhammad Rasyid Rida berkata tak ada persyaratan bagi orang Yahudi, Nasrani, dan

${ }^{103}$ Hamka, Tafsir al Azhar, Jilid. 1,..., h.265

104 Hal ini, sebagaimana pandangan Muhammad Rasyid Rida dalam Tafsir al-Manar, bahwa Q.S. al-Baqarah (2:62) dan al-Ma'idah (5:69) itu membicarakan keselamatan ablulkitab yang risalah Nabi Muhammad belum atau tidak sampai kepada mereka, sehingga mereka tidak diwajibkan
Sabi'ah untuk beriman kepada Nabi Muhammad. ${ }^{104}$

Buya Hamka menyebutkan dalam menafsirkan ayat diatas, "kesan pertama yang dibawa oleh ayat ini ialah perdamaian dan hidup berdampingan secara damai di antara pemeluk sekalian agama dalam dunia ini". ${ }^{105}$ Hamka merasa cemas terhadap pemeluk agama yang fanatik. Yang kadang saking fanatiknya, imannya bertukar dengan cemburu, "orang yang tidak seagama dengan kita adalah musuh kita." Dan ada lagi yang bersikap agresif, menyerang, menghina dan menyiarkan propaganda agama mereka dan kepercayaan yang tidak sesuai ke dalam daerah negeri yang telah memeluk suatu agama. ${ }^{106}$ Itu semua menjadi kecemasan Buya Hamka. Menurut Hamka ayat ini dengan jelas menganjurkan persatuan agama, jangan agama dipertahankan sebagai suatu golongan, melainkan hendaklah selalu menyiapkan jiwa mencari dengan otak dingin, manakah dia hakikat kebenaran. Iman kepada Allah dan hari akhirat diikuti oleh amal yang saleh. ${ }^{107}$

\section{Sementara dalam Tarjuman al-Mustafid,}

Bahwasanya segala mereka yang percaya ia akan segala Nabi yang dahulu dan mereka yang Yahudi dan Nashara dan Shabi'in yakni suatu tha'ifah darpada Nashara atau Yahudi, barang siapa percaya daripada mereka itu akan Allah Ta'ala dan akan hari Kiamat dan mengerjakan mereka itu akan amal yang saleh, maka adalah bagi mereka itu pahala segala amal mereka itu pada Tuhan mereka itu dan tiada takut atas mereka itu dan tiada mereka itu yang "percintaan". ${ }^{108}$

Menurut Said Aqil Siraj setiap agama atau kepercayaan memiliki jalan keselamatan masingmasing. Asalkan beriman kepada Allah, hari akhir, dan beramal saleh, maka keselamatan akan diperolehnya. Berhubungan dengan kedua ayat tersebut di atas, Said Aqiel Siradj menjelaskan:

"Ayat tersebut di sisi lain, menggoreskan suatu pemahaman yang akan meredam kontroversi antar agama-agama di dunia.

beriman. Lihat Abdul Moqsith, Argumen Pluralisme Agama (Jakarta: Katakita, 2008).

105 Hamka, jilid I h. 169.

106 Ibid

${ }^{107}$ Ibid, h, 169-170.

108 (al-Tarjuman al-Mustafid: 12) 
Kalau kita renungkan secara mendalam, disertai dengan sikap tidak emosional serta $b i$ busni al-niyyat, ayat di atas tidak hanya meretaskan benteng-benteng syari'ah yang bersifat dzanniyat, tetapi juga memupus pagar-pagar absolutisme agama yang banyak terefleksi pada doktrin-doktrin teologi. Bagi Allah SWT, dalam nash ayat tadi, kebajikan dan balasan baik (pahala, surga) tidak akan melihat predikat Muslim, Yahudi, Kritiani, Majusi, Budhis, Hinduis, penganut Kong $\mathrm{Hu}$ Chu ataupun lebellebel agama lainnya, namun titik tekannya hanya pada kemaun mereka beriman kepada-Nya dan kehidupan akhirat serta beramal shalih". ${ }^{109}$

M. Quraish Shihab memberikan catatan penting terkait ayat ini yaitu, " bahwa surga dan neraka adalah bak prerogratif Allab memang harus diakui. Tetapi bak tersebut tidak menjadikan semua agama sama dibadapan-Nya. Babwa bidup rukun dan damai antar pemeluk agama sesuatu yang mutblak dan tuntutan agama, tetapi cara untuk mencapai hal itu bukan dengan mengorbankan ajaran agama. Caranya adalah bidup damai dan menyerabkan kepada-Nya semata untuk memutuskan di hari kemudian kelak, agama siapa yang direstui-Nya dan agama siapa pula yang keliru, kemudian menyerabkan pula kepada-Nya penentuan akbir, siapa yang dianugerabi kedamaian surga dan siapa pula yang akan takut dan bersedih. ${ }^{110}$ 


\section{Penutup}

Dari pemaparan tersebut di atas menunjukkan bahwa negeri Nusantara yang memiliki pluralitas suku, bangsa, budaya, dan agama ini, juga disertai oleh pemahaman yang sama dari para mufasir Nusantara dalam memaknai isu-isu tentang pluralisme agama. Dalam hal inil Islam menunjukkan bahwa isu-isu pluralisme agama khususnya tentang pengakuan akan eksistensi agama lain; memberinya hak untuk hidup berdampingan saling menghormati pemeluk agama lain tanpa ada unsur kecurigaan; Larangan adanya unsur paksaan dalam beragama; dan pengakuan keselamatan pada masing-masing agama, telah dikupas dan dibahas oleh para mufasir nusantara.

Tidak ada perbedaan mendasar tentang prinsip utama dari ajaran-ajaran tersebut. Islam memerintahkan umatnya untuk menghormati agama orang lain, tidak berbuat teroris, selalu menjaga perdamaian di mana pun berada, dan menghormati manusia manapun sebagai manusia. Karena semua manusia layak untuk dihormati dan dijaga jiwa raganya. Kendati demikian, Islam tidak menutup kemungkinan adanya penafsiran yang berbeda dalam beberapa ayat al-Qur'an. Hal itu bukan lantaran Islam tidak konsisten dengan ajarannya, akan tetapi secara tidak langsung mengajarkan kepada umat bagaimana seharusnya mempraktekkan toleransi kepada mereka yang memiliki pemikiran yang berbeda. Lebih dari itu, keberagaman bentuk penafsiran dalam khazanah keilmuan Islam Nusantara, khususnya, menjadi gambaran bagaimana Islam mengejawantah dalam kehidupan berbangsa dan bermasyarakat Indonesia, hingga pada semboyan kebangsaan yang berbunyi: "Bhinneka Tunggal Ika", berbedabeda tetapi tetap satu jua. Walla hu a'lam bi alShowab. 


\section{DAFTAR KEPUSTAKAAN}

A.Hasan, Tafsir Al Furqan cet II (Surabaya: Al Ikhwan, 1986)

Abdul Moqsith Ghazali, "Membangun Teologi Pluralis", dalam Media Indonesia, Edisi Jumat, 24 Mei 2000. Argumen Pluralisme Agama (Jakarta, Kata Kita, 2009)

Abdul Munir Mulkhan, Ajaran dan Jala Kematian Syekh Siti Jenar (Yogykarta, Kreasi Wacana, 2008)

Abdullah Saeed, Pemikiran Islam: Sebuah Pengantar, terj (Yogyakarta: Kaukaba, 2014)

Abdur Ra'uf al-Sinkili, Tarjuman al-Mustafid, (Mumbai: Nelini Berindra, Ahmad Abad, 1951)

Abdurrahman Wahid, Islamku Islam Anda Islam Kita, Jakarta: The Wahid Institute, 2006)

Abuddin Nata, (ed.) Asas-asas Pluralisme dan Toleransi dalam Masyarakat Madani, (Jakarta : PT. Grasindo, 2002),

Adam Schward, A Nation in Waiting: Indonesia Search for Stability (Washing \& Unwin, 1999)

Ahamad Musthofa al-Maraghi, Tafsir AlMaraghi, (Semarang : Toha Putra, 1993)

Ahmad al-Sāwī al-Mālikī, Hāshiyat al-'Allāmah alSäwi alā Tafsìr al-Jalälayn, vol. 2 (Beirut: Dār al-Fikr, 1993)

Ahmad Warson Munawwir, Kamus al-Munawwir, (Yogyakarta: Unit Pengadaan Bukubuku ilmiah Keagamaan Pondok Pesantren, 1984)
Ainul Yaqin, Pendidikan Multikultural (Yogyakarta : Pilar Media, 2005)

Alford T. Welch, "Studies in Qur'an and Tafsir" JAAR., Vol 47, 1979,

al-Musnad, edisi Ahmad Muhammad Shäkir, vol. 7 (Mesir: Maktabat al-Turāth alIslāmī, t.th.),

Alwi Shihab, "Menyingkapi Pluralisme Agama", dalam Republika, edisi 9 Agustus 2005 ,

Indonesia, Sebuab Tinjauan Historis",
ed Nurul A Rustamdji, (Bandung:
Mizan, 1997),
Terbuka Dalam Beragama, (Bandung:
Mizan, 1998),

Amir Muslims Hussein, "Pluralism, and Interfaith Dialogue," in Progresive Muslims; on Justice, Gender and Pluralism, Omid Safi (ed) (Oxford: One World Publications, 2003),

Amirulloh Syarbini, Al-Qur'an dan Kerukunan Hidup Umat Beragama (Bandung: Quanta, 2011),

Anis Malik Thoha, Tren Pluralisme Agama, Tinjauan Kritis, (Jakarta: Perspektif Kelompok Gema Insani, n.d.),

Badr al-Din al-Zarkasyi, selanjutnya disebut alZarkasyi, al-Burban fi 'Ulum alQur'an, Jilid II, Isa al-Babiy alHalabi, Mesir,1972,

Bagus Lorens. Kamus Filsafat (Jakarta:PT.Gramedia pustaka utama, 2000)

Bahtiar Effendy, "Disartikulasi Pemikiran Politik Islam?", dalam Oliver Roy, L'échec de l'Islam politique, diterjemahkan oleh Harimurti dan Qamaruddin SF dengan judul 
Gagalnya Islam Politik (Jakarta: Serambi, 1996),

Bishri Mustafa, al-Ibriz li Ma'rifati Tafsiri al-Qur'an al-Aziø, (Kudus: Menara Kudus, t.t.)

Budhy Munawar Rahman, Islam Pluralis: Wacana Kesetaraan Kaum Beriman (Jakarta: Paramadina, 2001)

dan Moh Shofan, Sekularisme, Liberalisme, dan Pluralisme (Jakarta: Gramedia Widiasarana Indonesia, 2010),

Reorientasi Pembaruan

Islam: Sekularisme, Liberalisme dan Pluralisme, Paradigma Baru Islam Indonesia (Jakarta: Lembaga Studi Agama dan Filsafat (LSAF) dan Paramadina, 2010)

Burhan Bungin, Metodologi Penelitan Kualitatif, (Jakarta: Raja Grafindo Persada, 2006)

Choirul Mahfud, Pendidikan Multikultural. (Yogyakarta: Pustaka Pelajar, 2009)

Elias A. Elias, Modern Dictionary Arabic-English, Dar Gharib li al-Tiba'ah, Kairo, 1976,

Farid Essack, Qur'an, Liberation \& Pluralism: An Islamic Perspective of InterReligious Solidarity Against Oppression) (England: One World Publications, 1998)

Farir Esack, Membebaskan yang Tertindas: AlQur'an, Liberalisme dan Pluralisme, (Bandung : Mizan 2000), hlm. 206207

Fazlur Rahman, dkk., Agama untuk Manusia, Editor Abdul Aziz. Sachedina, (Yogyakarta: 2002),

Gavin W. Jones, "Agama-Agama di Indonesia: Sejarah dan Perkembangannya", dalam Agama dan Tantangan Zaman,
Pilihan Artikel Prisma 1975-1984 (Jakarta: LP3ES, 1985),

H. Abdullah SA, "Kebebasan Beragama dalam Perspektif al-Qur'an (Suatu Pendekatan Tafsir Mawdu'i)", dalam Tesis, (Surabaya: Hukum Islam dalam Ilmu Agama Islam Bidang Konsentrasi Syari'ah IAIN Sunan Ampel Surabaya, 2002)

Hamka, Tafsir Al-Azhar, (Jakarta : Pustaka Panjimas, 1984)

Harold Coward, Pluralism in the World Religions: A Short Introduction (Oxford: One World Publications, 2000)

Hasbi Ash Shiddieqy, Tafsir al-Bayan, Vol. 1 (Bandung: PT. Al Am arif, t.th)

Hornby, As., Oxford Advanced Learner's Dictionary of Current English, (Oxford : University Press, 2000),

Howard M. Federspiel, Kajian al-Qur'an di Indonesia, terj. Tajul Arifin, (Bandung: Mizan, 1996)

Ibn Jarîr at-Thabarî, Jâmi' al-Bayân 'an Ta'wil Ayjil Qur'ân. Beirut: Dâr al-A'lâm dan Dâr Ibn Hazm, 2002, juz 1,

Ibn Kathīr, Tafsìr Ibn Kathìr, vol. 1 (Beirut: Dār al-Fikr, 1986)

Islah Gusmian, “Tafsir al-Qur'an dan Kekuasaan; Menelusuri Jejak Dealektika Tafsir al-Qur'an dan Praktik Politik Rezim Orde Baru", dalam AICIS XIV (2014).

Khazanah Tafsir Indonesia dari Hermenutika bingga Ideologi (Jakarta: Teraju, 2002),

Isnatin Ulfa, "Perspektif al-Qur'an tentang Pluralisme Agama (Tela'ah Komparatif terhadap Pluralisme Agama dalam Tafsir Jami' al-Bayan dan Tafsir alMizan)", dalam Tesis, (Surabaya: Hukum Islam dalam 


\section{NUSANTARA; Journal for Southeast Asian Islamic Studies \\ Vol. 17, No. 1, Juni 2021}

Ilmu Agama Islam Bidang Konsentrasi Syari'ah IAIN Sunan Ampel Surabaya, 2003)

Jalal al-Din Abd al-Rahman al-Sayuthi, selanjutnya disebut al-Suyuthi, alItqan Fi Ulum al-Qur'an,Dar al-Fikr, Beirut Libanon, tt,

Jalāl al-Dīn al-Suyūtī dan Jalāl al-Dīn al-Mahallī, Tafsìr al-Qur'ān al-'Azìm (Tafsīr alJalālayn), vol. 1 (Semarang: Toha Putra, t.th.),

John Hick, dalam Mircea Eliade (ed), The Encyclopedia of Religion, (New York: MacMillan Publishing Company, 1987), Vol. 12, hal. 331.

John L. Esposito, Islam and Politics (Syracuse: Syracuese University Press, 1984)

Junaidi Idrus, Rekonstruksi Pemikiran Nurcholis Madjid : Membangun Visi dan Misi Baru Islam Indonesia, (Yogyakarta : Logung Pustaka, 2004)

Khaled Abou El Fadl, Atas Nama Tuban (Jakarta: Serambi, 2004)

Klaus Krippendorff, Analisis isi:pengantar teori dan metodologi, (Jakarta: Rajawali Pres, 1991)

L. Carl Brown, Religion and State: The Muslim Approaches to Politics (New York: Columbia University Press, 2000)

Lesslie Newbigin, Injil Dalam Masyarakat Majemuk (Jakarta: Gunung Mulia, 1993)

M. A. Aziz Masyhuri, 99 Kiai Kharismatik Indonesia: Biografi, Perjuangan, Ajaran dan Do'a-do'a Utama yang Diwariskan (Yogyakarta: Kutub, 2008)

M. Nurdin Zuhdi, Pasaraya Tafsir Indonesia, (Yogyakarta: Kaukabapa. 2014),
M. Qurais Shihab, Membumikan al-Qur'an: Mukjizat Al-Qur'an. Cet. I. (Bandung: PT Mizan Pustaka, 2007) Tafsir Al-Misbah Pesan, Kesan dan Keserasian Al-Qur'an (Jakarta: Lentera Hati, 2005),

M. Yunan Yusuf, Corak Pemikiran Kalam Tafsir alAzhar (Jakarta: Pustaka Panji Mas, 1990),

Malik bin Nabi, Fenomena al-Qur'an, terj. Saleh Mahfoed, (Bandung: al-Ma'rif, 1983)

Manna Khalil al-Qattan, Mabahits fi Ulum alQur'an, Mansyurat al-Ashr al-Hadits, Beirut, Libanon,tt,

Media Zainul Bahri, Satu Tuban Banyak Agama: Pandangan Sufistik Ibn 'Arabi, Rumi, Dan Al-jili (Bandung: Mizan, 2011)

Mishbahus Surur, "Metode dan Corak Tafsir Faidh ar-Rahman Karya Muhammad Shaleh Ibn Umar AsSamarani" (Skripsi--IAIN WaliSongo Semarang, 2011),

Moc. Nur Ichwan, "Literatur Tafsir Qur'an Melayu-Jawi di Indonesia: Relasi Kuasa, Pergeseran dan Kematian" dalam Visi Islam Jurnal Ilmu-ilmu Keislaman, Volume 1, Nomor 1, Januari 2002,

Muhamad Arif Mustofa, "Kerukunan Umat Beragama (Studi Analisis Tentang Non Muslim, Ahlul Kitab \& Pluralisme)", dalam Jurnal MIZANI VOL. IX, NO.1, Februari 2015.

Muhammad Ali al-Shabuniy, al-Tibyan fi Ulum alQur'an, Dar al-Irsyad, Beirut, tt,

Muhammad ar-Râzi Fakhruddin, Tafsîr al-Kabîr wa Mafâtih al-Ghaib. (Beirut: Dâr aFikr, 2005), juz 1 
Muhammad Bâqir al-Nashirî, Mukhtashar Majma' al-Bayân (Kairo: Dâr al-Ma'rifah, t.t),

Muhammad Husayn al-Dhahabî, al-Tafsîr wa alMufassirûn, Vol. 3 (Kairo: Dâr alKutub al-Hadîthah, 1961),

Muhammad ibn Umar Nawawi al-Jawi alBantani, Marab al-Labid li Kasyfi Ma'na al-Qur'an al-Majid, (Beirut: Dar al-Kutub al-'Ilmiyah, 1997)

Muhammad ibn Umar Nawawi al-Jawi alBantani, Marab al-Labid li Kasyfi Ma'na al-Qur'an al-Majid, Juz I, (Beirut: Dar al-Kutub al-'Ilmiyah, 1997)

Muhammad Rasyid Ridha, Tafsîr al-Qur'ân alHakîm, juz III (Beirut: Dâr al-Fikr, 1964)

Mun'im A. Sirri, Polemik Kitab Suci, (Jakarta: Gramedia, 2013)

Mun'im Sirry (ed.), Fiqih Lintas Agama : Membangun Masyarakat InklusifPluralis, Jakarta : Yayasan Paramadina, 2004)

Nashruddin Baidan, Perkembangan Tafsir al-Qur'an di Indonesia (Solo: Tiga Serangkai Pustaka Mandiri, 2003)

Nurcholis Madjid, Islam Kemodernan dan Keindonesiaan (Bandung : Mizan, 1998)

Islam, Doktrin Peradaban, (Jakarta: Paramadina, 1992)

Oliver Roy, The Failure of Political Islam, translated by Carol Volk (Cambridge: Harvard University Press, 1992)

Rif'at Syauqi Nawawi, Rasionalitas Tafsir Mubammad Abdub Kajian Masalab Akidah dan Ibadah, Paramadina, Jakarta, 2002,
Said Aqiel Siradj, Ablussunnah wal Jama'ah dalam Lintas Sejarah. (Yogyakarta: LKPSM, 1999)

Saiful Amin Ghofur, Profil Para Mufassir (Yogyajarta: Pustaka Insan Madani, 2008),

Salman Harun, "Hakekat Tafsir Tarjuman alMustafid Karya Syekh Abdurrauf Singkel" (Disertasi--IAIN Syarif Hidayatullah Jakarta,1988)

Subkhi Ridho, "Kelas Menengah Muslim Baru dan Kontestasi Wacana Pluralisme di Media Sosial" dalam Jurnal Pemikiran Sosiologi Volume 4 No. 2 , Agustus 2017

Sugiono, Metode Penelitian Kuantitatif, Kualitatif, dan R\&D, (Bandung: ALFABETA,2011)

Suharsimi Arikunto, Prosedur Penelitian, (Jakarta: Rineka Cipta, 1993)

Syaikh Imam Al Qurthubi, Tafsir Al Qurthubi [17], diterjemahkan dari Al Jami' li Abkaam Al Qur"an, terj. Akhmad Khatib, (Jakarta: Pustaka Azzam, 2009),

Tantawi Jauhari, al-Jawâhir fì Tafsîr al-Qur'ân (Kairo: Dâr al-Fikr, t.t.)

Taufikurrahman, "Kajian Tafsir di Indonesia", dalam Jurnal Mutawâtir Vol.2|No.1| Januari -Juni 2012|

Tengku Muhammad Ash-Shiddieqy, Tafsir AlQur'anul Majid: An-Nur, (Semarang : : Pustaka Rizki Putra, 2000), Cet. II.,

Tim Penterjemah Depag RI, al-Qur'an dan Terjemahnya, Khadim al-Haramayn, Makkah al-Mukarromah, 1991,

TM Hasbi Ash Shiddieqy, Sejarah dan Pengantar Ilmu Hadits (Semarang: Pustaka Rizki Putra, 1999), 
NUSANTARA; Journal for Southeast Asian Islamic Studies

Vol. 17, No. 1, Juni 2021

Yudi Latif. Dialektika Islam: Tafsir Sosiologis atas Sekularisasi dan Islamisai di Indonesia (Yogyakarta: Jalasutra, 2007),

Ziaul Haque, $W$ abyu dan Revolusi, terj. E. Setiyawati Al Khatab (Yogyakarta: LKiS, 2000),

Zuhairi Misrawi dalam bukunya Al Qur'an Kitab Toleransi: Inklusivisme, Pluralisme, dan Multikulturalisme (Jakarta: Fitrah, 2007) 